\title{
Generation of Late Cretaceous silicic rocks in SE China: Age, major element and numerical simulation constraints
}

\author{
Cheng-Hong Chen ${ }^{\mathrm{a}, *}$, Chi-Yu Lee ${ }^{\mathrm{a}}$, Hsueh-Yu Lu ${ }^{\mathrm{b}}$, Pei-Shan Hsieh ${ }^{\mathrm{a}}$ \\ a Department of Geosciences, National Taiwan University, No.1, Roosevelt Road Section 4, Taipei 106, Taiwan \\ ${ }^{\mathrm{b}}$ Department of Earth and Environmental Sciences, National Chung Cheng University, Chiayi, Taiwan
}

Received 24 July 2007; accepted 20 August 2007

\begin{abstract}
Rhyolite-dominating bimodal volcanic suites (rhyolite/basalt), mafic dikes and A-type granites distribute from N Zhejiang to $\mathrm{S}$ Fujian over $800 \mathrm{~km}$ in the Southeast Coast Magmatic Belt (SCMB) - the Late Yanshanian (LY) orogenic belt in SE China. Data of ${ }^{40} \mathrm{Ar} /{ }^{39} \mathrm{Ar}$ and $\mathrm{K}-\mathrm{Ar}$ whole-rock ages and LA-ICPMS U-Pb zircon ages indicate that rhyolitic volcanism (101-72 Ma) is contemporaneous with the A-type granitic intrusions (100-90 Ma) and mafic dike injections (94-77 Ma). This time span is used to define the upper volcanic series in Zhejiang-Fujian areas. One striking feature of rhyolites in the SCMB is that many are strongly peraluminous (SP) and others, mostly restrict in Fujian, are peralkaline to mildly peraluminous (P-MP) and chemically resemble A-type granites. The SP character is unique among well-known large rhyolite provinces worldwide. Based on experimental works for a common thermal regime and inherited zircon age information, we suggest that SP and P-MP rhyolites represent low pressure melting of the felsic (quartzofeldspathic) granite ( \pm metapelite) and the accompanied granodioritic, tonalitic and trondhjemitic member of the core complex assemblage, respectively, to account for the decreasing aluminosity. They could have also been contaminated by young igneous rocks, and ancient crust to a lesser degree, during ascent to the surface. Plate subduction and lithosphere extension processes, respectively, are numerically simulated for the magma generation of these rhyolites using the mafic underplating model. Results suggest that the most effective controlling factor to generate SP and associated P-MP (A-type) magmas during 95-80 Ma is thinning of the lithosphere thickness with a high exhumation rate. Under this circumstance, the core complex assemblage can be uplifted to lower level of the crust and match the constraint of experimental works.
\end{abstract}

(c) 2007 Elsevier Ltd. All rights reserved.

Keywords: Strongly peraluminous (SP) rhyolites; A-type granites; Mafic underplating; Late Yanshanian orogeny; SE China

\section{Introduction}

The study of orogenesis is one of the major focuses among geologists because it is fundamentally important to the understanding of continental growth throughout geological time. Extensive orogenic movements commonly lead to vigorous magmatic activities in the lower to upper crust levels. Vast intermediate to acidic plutonic and silicic volcanic rocks, distributed over an area of ca. 204,000 km² in S China and known as products of the Yanshanian magmatism (Zhou et al., 2006), provide important records for

\footnotetext{
* Corresponding author. Tel.: +88623366 5872; fax: +886223636095. E-mail address: chench@ntu.edu.tw (C.-H. Chen).
}

the Mesozoic crustal evolution of the Cathaysia Block. Plutonism and volcanism occurred during middle to late Jurassic times are related to the Early Yanshanian (EY) orogeny and relevant rocks are mainly distributed in the interior of this Block; those occurred during early Cretaceous are related to the Late Yanshanian (LY) orogeny and more restricted in SE China coastal areas (Chen and Jahn, 1998). The LY magmatism is well accepted as had been affected by the paleo-Pacific subduction system in the continental margin (e.g., Zhou and Li, 2000) and the product is best exemplified by igneous rocks in the Southeast Coast Magmatic Belt (SCMB) and the accompanied core complex in the Changle-Nanao Metamorphic Belt (CNMB) (Fig. 1). 


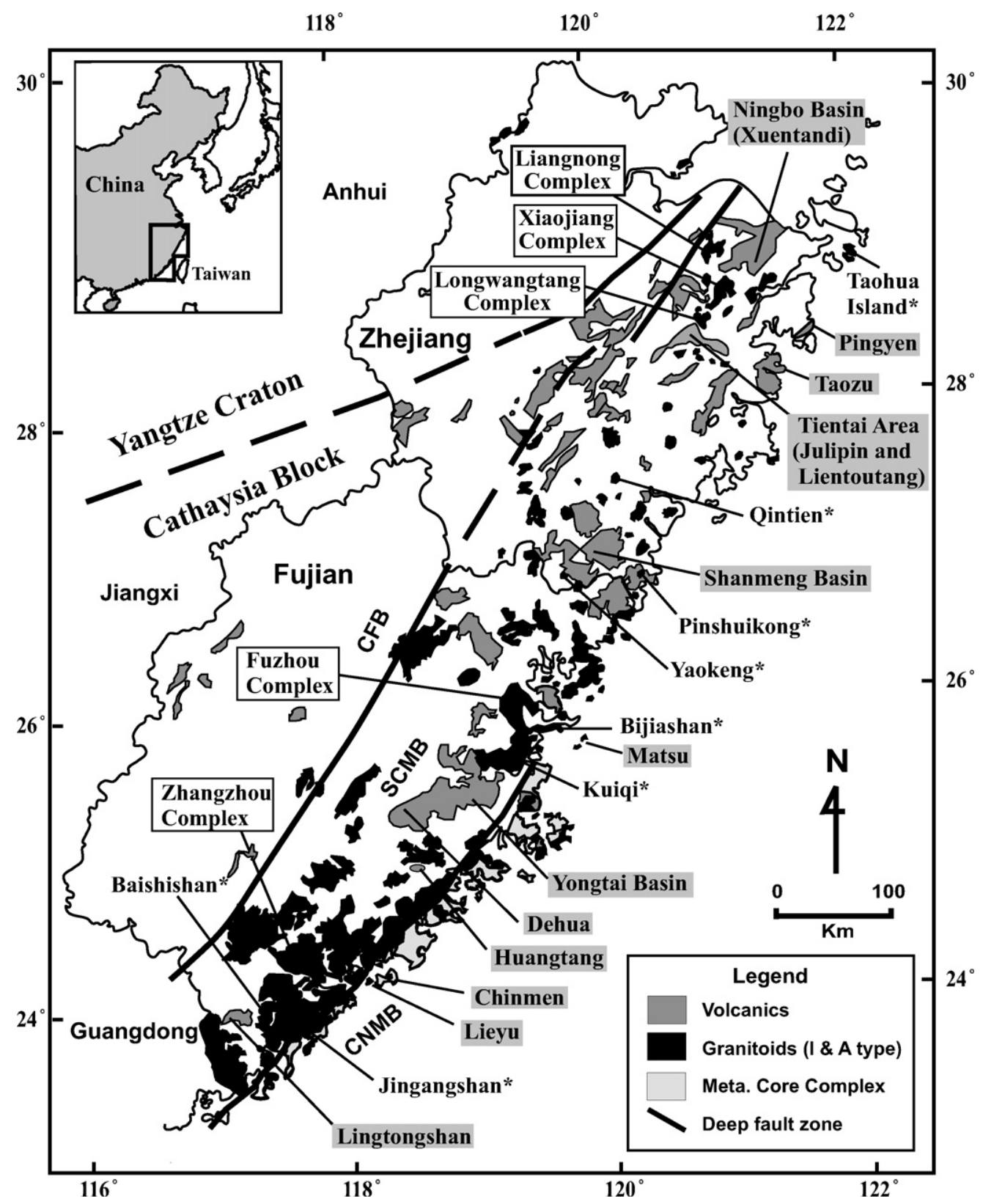

Fig. 1. Distribution of Cretaceous igneous rocks in the Zhejiang-Fujian area, SE China (modified from BGMRZJ, 1989 and BGMRFJ, 1985). CNMB: Changle-Nanao Metamorphic Belt; SCMB: Southeast Coast Magmatic Belt; CFB: Cathaysia Folded Belt (equivalent of the Cathaysia interior in the text). Locations for the 110-99 Ma I-type granitoids (Chen and Jahn, 1998) are framed, for the 100-90 Ma A-type granites (Chen et al., 2000; Qiu et al., 2004) are marked with an asterisk, and the studied rhyolite-dominating bimodal volcanics and mafic dikes are shaded. Mafic dikes mostly injected into the granitic rocks in Fuzhou, Matsu, Zhangzhou and Chinmen (including Lieyu).

The core complex in the CNMB consists of a series of gneissic-foliated, high aluminous rocks including gabbro, trondhjemite, tonalite and granodiorite and is associated with schistosed felsic granites and metapelites. These rocks have been suggested to be emplaced during $140-110 \mathrm{Ma}$, or $130-110 \mathrm{Ma}$ if only the trondhjemite-tonalite-granodiorite assembalge is concerned (Chen et al., 2004, 2006 and references therein). In the SCMB, plutonic rocks are high-K calc-alkaline I-type granitoids, mainly including granodiorite, monzogranite and syenogranite, formed between 110 and $99 \mathrm{Ma}$ (Chen and Jahn, 1998; Chen et al., 2000). Less voluminous and sporadically distributed A-type granites emplaced at 101-90 Ma (Martin et al., 1994; Chen et al., 2000; Qiu et al., 2004). The change from calc-alkaline Itype to more alkaline A-type shallow plutonism through time indicates that magmas were developed under the progressive extensional environment $(\mathrm{Li}, 2000)$.

LY volcanic rocks in the eastern Zhejiang and Fujian, i.e., north and south SCMB, are traditionally divided into the lower and upper series, mainly with high-K dacites and rhyolites (and minor andesites and basalts) in the former and rhyolite-dominating/basalt bimodal suites in the latter 
(Tao et al., 2000). In addition, mafic dikes are often found intruding I- and A-type granitic plutons, especially in Fujian. Previous geochronological works indicate that rocks of the lower series basically erupted during $135-110 \mathrm{Ma}(\mathrm{Li}$ et al., 1988, 1989; Lapierre et al., 1997) or even older (NIGMR, 1987), and those of the upper series were synchronous to the I-type granitoids and thus regarded as their volcanic counterparts (Charvet et al., 1994; Lapierre et al., 1997). However, some ages for the upper series are problematic mainly due to conflicts with the field relationship (Tao et al., 2000) or the age interval of 110-99 Ma for I-type rocks (Xing et al., 1999). Recently, Lin (2001) proposed that they represent the epilogue of LY magmatic events as a consequence of the progressive development from Itype granitoids to A-type granaites and then rhyolite/basalt bimodal volcanics commonly seen in the orogenic belt (e.g., Pitcher, 1997). Therefore, precise age determination of these rocks becomes critical. In this paper, we focus on the systematic age dating and chemical analysis for volcanic rocks of the upper series as well as mafic dikes for better understanding the silicic magma generation and the relation to the associated basaltic activities. With the geochronological and geochemical constraints, tectonic control of silicic magma generation in the LY orogenic cycle is sought with numerical simulations. These allow us to more precisely tie the LY magmatic events to the climax of extension in the SE China continental margin.

\section{Distribution of igneous rocks in the SCMB}

I-type igneous complexes are represented by plutons of Liangnong $\left(90 \mathrm{~km}^{2}\right)$, Xiaojiang $\left(210 \mathrm{~km}^{2}\right)$ and Longwangtang $\left(300 \mathrm{~km}^{2}\right)$ in Zhejiang, and Fuzhou $\left(1100 \mathrm{~km}^{2}\right)$ and Zhangzhou $\left(900 \mathrm{~km}^{2}\right)$ in Fujian. Amphibole geobarometry suggests that they were emplaced at depths of 5-7 km and were subjected to rapid cooling conditions (Chen et al., 2000). A-type granites, occurred as smaller bodies in Taohua Island, Pingshuikong, Qintien and Yaokeng and larger plutons like Kuiqi $\left(300 \mathrm{~km}^{2}\right)$, belong to the alkaline subgroup; and those occurred as larger bodies in Bijiashan $\left(140 \mathrm{~km}^{2}\right)$, Jingangshan $\left(176 \mathrm{~km}^{2}\right)$ and Baishishan $\left(180 \mathrm{~km}^{2}\right)$, belong to the aluminous subgroup (Fig. 1). The presence of $\mathrm{Na}$ - and $\mathrm{Fe}$-rich mafic minerals versus aluminous-rich minerals, such as spessartine garnet and muscovite, are characteristic features of these two subgroups (Hong et al., 1996; Qiu et al., 2004). Mafic dikes are often found to sharply crosscut the large I-type granitic plutons - indicative of basic magma invasions in the brittle zone. The Kuiqi pluton also hosts some synplutonic mafic dikes, but no precursor swarms of basaltic dikes for A-type granite (Pitcher, 1997) have been found.

Volcanic rocks of the upper series occupy a total area about $35,000 \mathrm{~km}^{2}$ in the SCMB (Zhou et al., 2006), with $30,000 \mathrm{~km}^{2}$ in Zhejiang and $5000 \mathrm{~km}^{2}$ in Fujian (Fig. 1). They are mainly composed of silicic rocks intercalated with small amounts of basalt in thick sequences of alternating volcano-sedimentary strata over $5000 \mathrm{~m}$ thick in some
NNE-trending, fault-bounded volcanic basins. Tuffs, tuffaceous breccias, ignimbrites and rhyolites are major lithologies for silicic volcanic rocks, and scarce basaltic sills have also been reported (Lapierre et al., 1997). Presumably representing typical rocks of the upper series based on lithological features, rhyolite/basalt bimodal suites of Xuentandi of the Ningbo Basin $\left(1050 \mathrm{~km}^{2}\right)$, Julipin and Lientoutang of the Tientai area $\left(750 \mathrm{~km}^{2}\right)$, the Shanmeng Basin $\left(700 \mathrm{~km}^{2}\right)$ and the Yongtai-Dehua Basin $\left(2550 \mathrm{~km}^{2}\right)$ are selected. In addition, mono-lithologic layers of rhyolite in Pingyen (few $\mathrm{km}^{2}$ ) and Taozu area $\left(780 \mathrm{~km}^{2}\right.$ ) in $\mathrm{N}$ Zhejiang and rhyolites of Huangtang and Jianwaishan-Lingtongshan areas $\left(210 \mathrm{~km}^{2}\right)$ in S Fujian are also included. Pingyen samples are characterized by containing abundant well rounded to oval basaltic inclusions (1-2 m) and being cut by basaltic dikes. Columnar sections showing the sampling site relative to the volcano-sedimentary sequences in these volcanic basins are depicted in Fig. 2.

Recently, the importance of silicic large igneous provinces (SLIPs) including the Taupo Volcanic Zone (New Zealand) has been envisaged (Bryan et al., 2002). Denudation of volcanic basins in the SE China continental margin that has resulted in many exposures of deeper level structural features, such as major intrusions and dike injections, reveals that the dimension of silicic-dominated igneous rocks in the SCMB is comparable to that of the Taupo Volcanic Zone $\left(\sim 15,000 \mathrm{~km}^{3}\right)$. Although these rhyolites might not really reach the SLIPs characteristics as proposed by Bryan et al. (2002), they can still provide useful information for the case of silicic-dominating volcanism associated with active continental convergent margins.

\section{Analytical methods}

Bimodal volcanic rocks and mafic dikes were dated using the step-heating ${ }^{40} \mathrm{Ar} /{ }^{39} \mathrm{Ar}$ technique to obtain an age spectrum, following the procedures described by Lo and Lee (1994). Mineral concentrates were irradiated under the THOR reactor in Tsing-Hua University (Hsinchu, Taiwan) and neutron flux gradients were monitored with MMhb-1 hornblende $(520.4 \pm 1.7 \mathrm{Ma})$ and LP-6 biotite $(127.7 \pm 1.4 \mathrm{Ma})$ standards. The instrument used for measuring the purified gas is the VG3600 mass spectrometer at the National Taiwan University. The plateau age was calculated as the weighted mean of apparent dates for at least three consecutive heating steps, and ages given by the total ${ }^{39} \mathrm{Ar}$ released from each step are indistinguishable at the $2 \sigma$ level. Theoretically, the ${ }^{40} \mathrm{Ar} /{ }^{39} \mathrm{Ar}$ dating system shall provide a widened flat spectrum of plateau age similar to the age on an intercept isotope correlation diagram $\left({ }^{36} \mathrm{Ar} /{ }^{40} \mathrm{Ar}\right.$ vs. ${ }^{39} \mathrm{Ar} /{ }^{40} \mathrm{Ar}$ plot). However, disturbed age spectra sometimes occur due mainly to the existence of tiny impurities in the dated samples (Bingen et al., 1998).

Here we present one example including the isotope ratios for gas released from each temperature step and their resultant apparent ages (Table 1), and ${ }^{40} \mathrm{Ar} /{ }^{39} \mathrm{Ar}$ wholerock age plateau spectra, together with the intercept age 


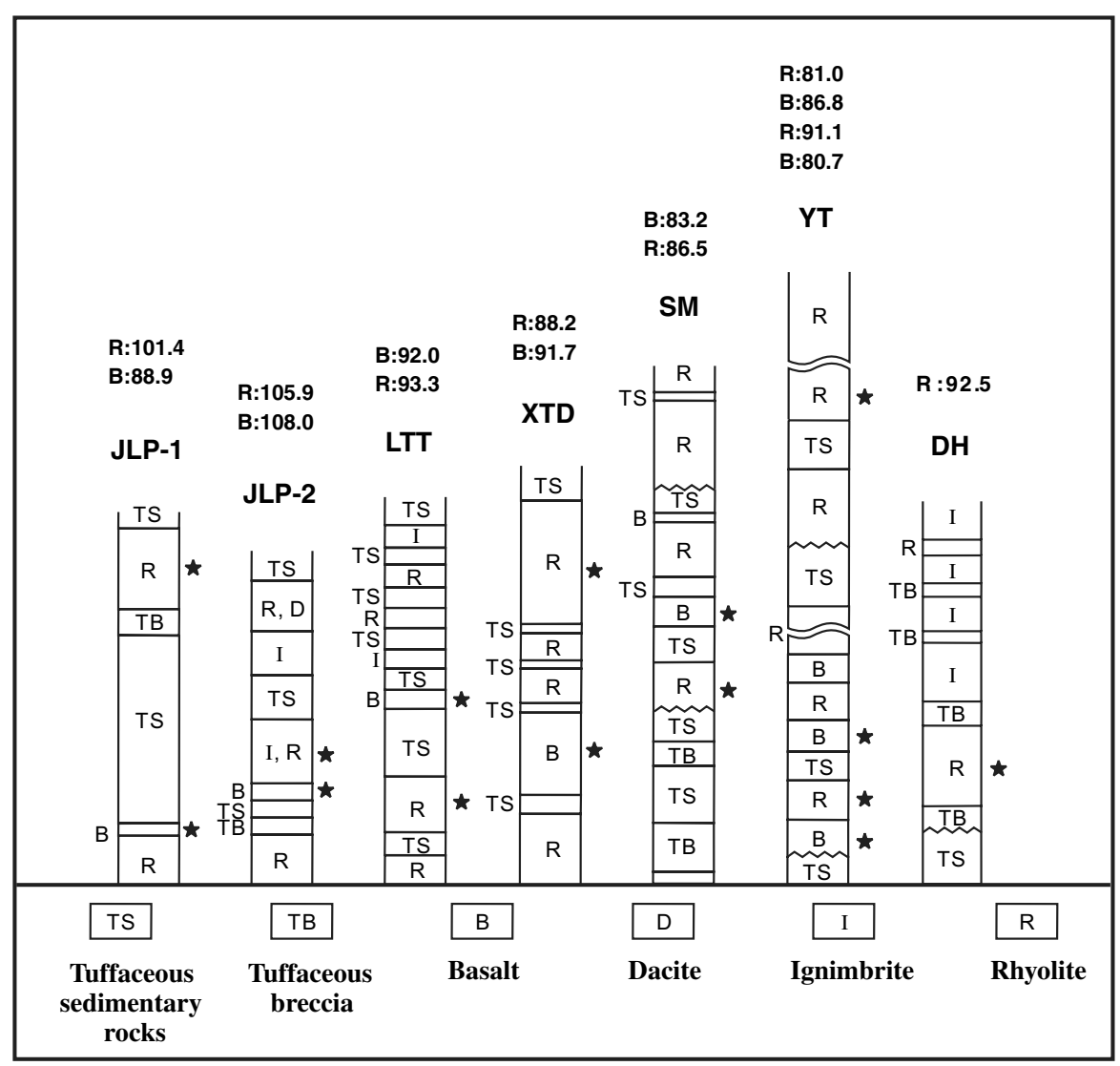

Fig. 2. Simplified columnar sections of bimodal volcanic sequences from major volcanic basins in the SCMB, with references to the section profiles of Xie et al. (1996) (JLP-1, Julipin Formation (?) of Julipin; JLP-2, Xishantou Formation of Julipin; LTT, Lientoutang Formation of Lientoutang; XTD, Guantou Formation of Xuentandi; SM, Chaochuan Formation of Shanmeng; YT, Shimaoshan Group of Yongtai and DH, Shiniushan Formation of Dehua). Asterisks denote the relative position of samples that their ages (Ma) have been determined and summarized above each column.

Table 1

Results of ${ }^{40} \mathrm{Ar} /{ }^{39} \mathrm{Ar}$ incremental heating experiments of a representative mafic dike (FJ92-PC01)

\begin{tabular}{|c|c|c|c|c|c|c|c|c|}
\hline$T\left({ }^{\circ} \mathrm{C}\right)$ & Cum. ${ }^{39} \mathrm{Ar}_{\mathrm{K}}$ & Atmos. $(\%)$ & ${ }^{36} \mathrm{Ar} /{ }^{39} \mathrm{Ar}$ & ${ }^{37} \mathrm{Ar} /{ }^{39} \mathrm{Ar}$ & ${ }^{38} \mathrm{Ar} /{ }^{39} \mathrm{Ar}$ & ${ }^{40} \mathrm{Ar} /{ }^{39} \mathrm{Ar}$ & ${ }^{40} \mathrm{Ar} /{ }^{36} \mathrm{Ar}$ & Date (Ma) \\
\hline 462 & .035 & 81.524 & $.5980 \mathrm{E}+00$ & $.9961 \mathrm{E}+00$ & $.1318 \mathrm{E}+00$ & $.2167 \mathrm{E}+03$ & $.3624 \mathrm{E}+03$ & $71.48 \pm .44$ \\
\hline 543 & .072 & 71.314 & $.3770 \mathrm{E}+00$ & $.6716 \mathrm{E}+00$ & $.9154 \mathrm{E}-01$ & $.1562 \mathrm{E}+03$ & $.4143 E+03$ & $79.77 \pm .46$ \\
\hline 640 & .182 & 38.705 & $.9658 \mathrm{E}-01$ & $.8045 E+00$ & $.3348 \mathrm{E}-01$ & $.7361 \mathrm{E}+02$ & $.7622 \mathrm{E}+03$ & $80.32 \pm .37$ \\
\hline 696 & .251 & 18.990 & $.3573 E-01$ & $.4964 \mathrm{E}+00$ & $.2214 \mathrm{E}-01$ & $.5542 \mathrm{E}+02$ & $.1551 \mathrm{E}+04$ & $79.92 \pm .38$ \\
\hline 773 & .316 & 23.981 & $.4784 \mathrm{E}-01$ & $.7053 \mathrm{E}+00$ & $.2493 \mathrm{E}-01$ & $.5876 \mathrm{E}+02$ & $.1228 \mathrm{E}+04$ & $79.53 \pm .40$ \\
\hline 847 & .397 & 26.673 & $.5505 \mathrm{E}-01$ & $.4038 \mathrm{E}+00$ & $.2524 \mathrm{E}-01$ & $.6090 \mathrm{E}+02$ & $.1106 \mathrm{E}+04$ & $79.50 \pm .37$ \\
\hline 919 & .513 & 31.616 & $.6957 \mathrm{E}-01$ & $.5739 \mathrm{E}+00$ & $.2914 \mathrm{E}-01$ & $.6492 \mathrm{E}+02$ & $.9331 \mathrm{E}+03$ & $79.04 \pm .36$ \\
\hline 992 & .686 & 30.553 & $.6601 \mathrm{E}-01$ & $.3335 E+00$ & $.2909 \mathrm{E}-01$ & $.6379 \mathrm{E}+02$ & $.9664 \mathrm{E}+03$ & $78.87 \pm .36$ \\
\hline 1026 & .737 & 33.995 & $.7675 \mathrm{E}-01$ & $.7913 E+00$ & $.3472 \mathrm{E}-01$ & $.6657 \mathrm{E}+02$ & $.8673 E+03$ & $78.27 \pm .39$ \\
\hline 1061 & .788 & 35.693 & $.8261 \mathrm{E}-01$ & $.7913 E+00$ & $.3562 \mathrm{E}-01$ & $.6825 \mathrm{E}+02$ & $.8262 \mathrm{E}+03$ & $78.19 \pm .39$ \\
\hline 1124 & .942 & 47.352 & $.1373 E+00$ & $.2272 \mathrm{E}+01$ & $.5136 \mathrm{E}-01$ & $.8534 \mathrm{E}+02$ & $.6216 \mathrm{E}+03$ & $80.08 \pm .37$ \\
\hline 1170 & .988 & 70.750 & $.3662 \mathrm{E}+00$ & $.5767 \mathrm{E}+01$ & $.9792 \mathrm{E}-01$ & $.1524 \mathrm{E}+03$ & $.4161 \mathrm{E}+03$ & $79.63 \pm .38$ \\
\hline 1199 & 1.000 & 89.199 & $.1081 \mathrm{E}+01$ & $.7682 \mathrm{E}+01$ & $.2364 \mathrm{E}+00$ & $.3574 \mathrm{E}+03$ & $.3307 \mathrm{E}+03$ & $69.27 \pm .73$ \\
\hline \multicolumn{9}{|c|}{ Sample mass $=0.1858 \mathrm{~g}$} \\
\hline \multicolumn{9}{|c|}{$J$-value $=0.10090 \mathrm{E}-02 \pm 0.45810 \mathrm{E}-05$} \\
\hline \multicolumn{5}{|c|}{ Integrated date $=79.0 \pm .4 \mathrm{Ma}$} & \multicolumn{4}{|c|}{${ }^{39} \mathrm{Ar}$ volume $=0.1127 \mathrm{E}-06 \mathrm{ccSTP} / \mathrm{g}$} \\
\hline \multicolumn{5}{|c|}{ Plateau date $=79.4 \pm 0.4 \mathrm{Ma}\left(542-1170^{\circ} \mathrm{C}\right)$} & \multicolumn{4}{|c|}{${ }^{40} \mathrm{Ar}^{*}$ volume $=0.5004 \mathrm{E}-05 \mathrm{ccSTP} / \mathrm{g}$} \\
\hline
\end{tabular}

Note: $J$-value: Weighted mean of three fusions of irradiation standard HD-B1 Biotite, having a K-Ar age of 24.00.4 Ma (Fuhrmann et al., 1987).

Date is calculated using the following decay constants: $\lambda_{\varepsilon}=0.581 \times 10^{-10} \mathrm{yr}^{-1} ; \lambda_{\beta}=4.962 \times 10^{-10} \mathrm{yr}^{-1} ; \lambda=5.543 \times 10^{-10} \mathrm{yr}^{-1} ;{ }^{40} \mathrm{~K} / \mathrm{K}=0.01167 \mathrm{atom}^{0} \%$ (Steiger and Jager, 1977).

Uncertainties for ${ }^{40} \mathrm{Ar}^{*}$ and ${ }^{39} \mathrm{Ar}_{\mathrm{K}}$ volumes are $5 \%$.

Cum. ${ }^{39} \mathrm{Ar}$ is the cumulative fractions of ${ }^{39} \mathrm{Ar}_{\mathrm{K}}$ and ${ }^{40} \mathrm{Ar}^{*}$ released in each step. Integrated date is the date and error calculated from the sum total gas from all steps; the error includes the error in $J$-value.

Plateau date is the data and error calculated from the sum total gas from those steps, the ages of which fall within 2 SD of each other; the error includes the error in $J$-value. 
(Icpt age) and its MSWD value calculated from the isotope correlation diagram, for sample FJ92-PC01 (Fig. 3a). For others, only the age plateau diagrams with the results of plateau and Icpt ages are shown (Fig. 3b and c). Total gas age (calculated from all temperature steps), plateau age and Icpt age for 11 rhyolites, 9 associated basalts and 9 mafic dikes are listed in Table 2, in which the recommended age for each dated sample and criteria of selection are also given.
Eleven samples of mafic dike were also dated using the $\mathrm{K}-\mathrm{Ar}$ method described by Tsao (1994). The instrument used is the VG1200S mass spectrometer equipped with double vacuum resistance furnace and gas extracting system at the Central Geological Survey (Taipei). Samples were heated up to $1300-1500{ }^{\circ} \mathrm{C}$ to ensure that gases were totally released. High purity ${ }^{38} \mathrm{Ar}$, with the ${ }^{40} \mathrm{Ar} /{ }^{38} \mathrm{Ar}$ and ${ }^{36} \mathrm{Ar} /{ }^{38} \mathrm{Ar}$ ratios fixed at $2.2 \times 10^{-3}$ and $3.4 \times 10^{-5}$, is added as the spike. In this setup, the ${ }^{40} \mathrm{Ar} /{ }^{36} \mathrm{Ar}$ ratio in the air is (a) FJ92-PC01

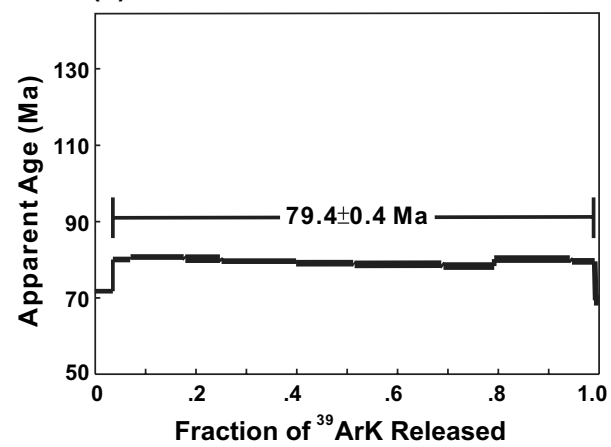

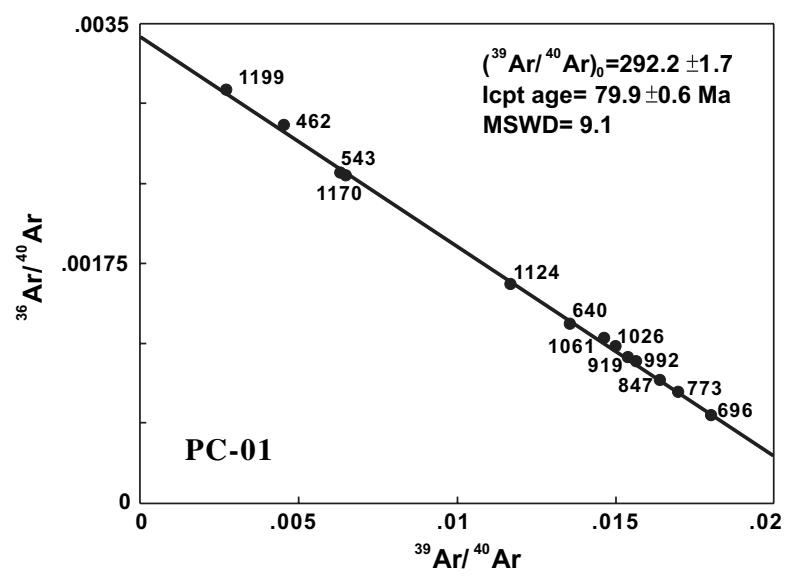

(b) Maficdikes

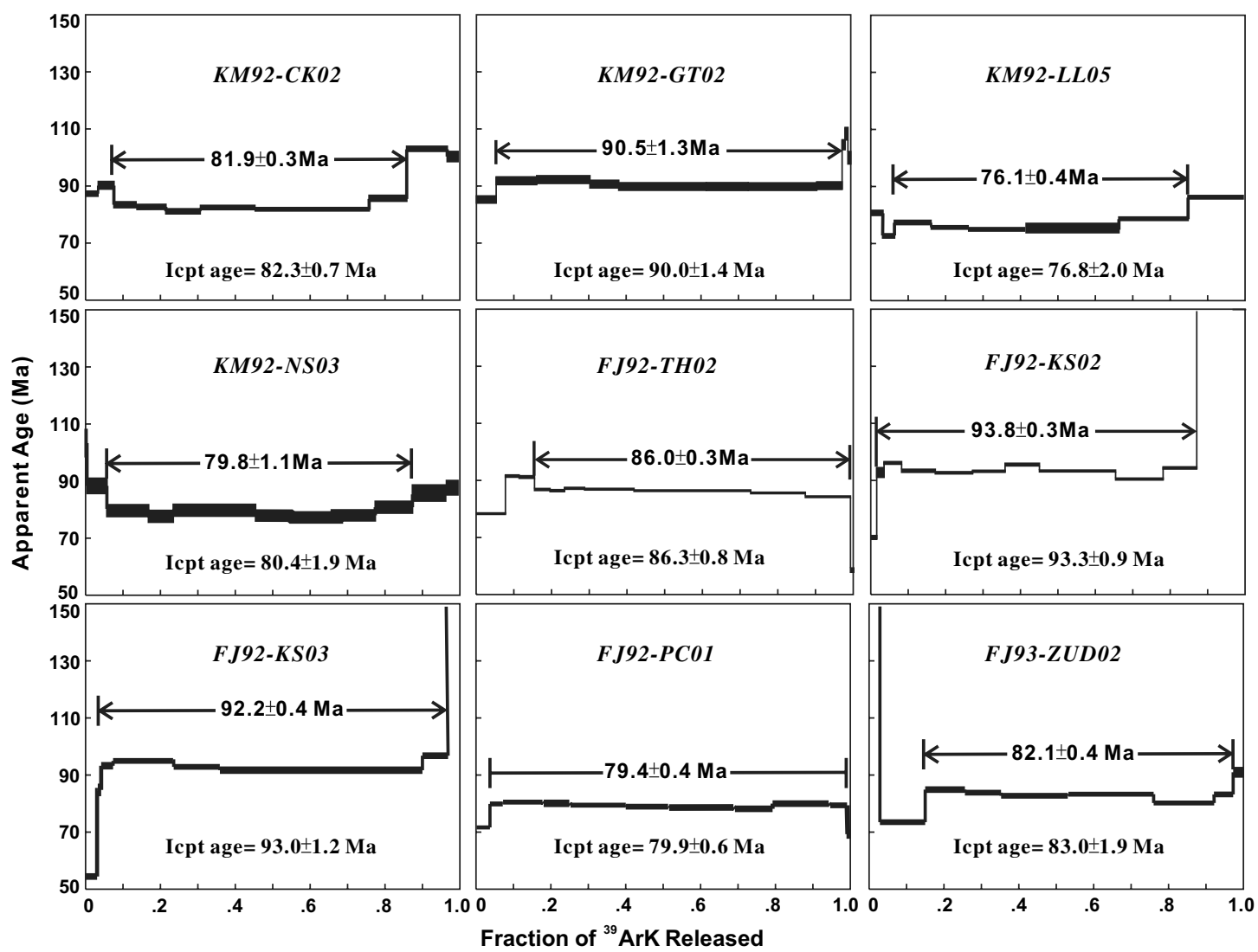

Fig. 3. (a) Example of age plateau plots, with data points of the intercept age (Icpt age, obtained separately from the correlation plots of ${ }^{36} \mathrm{Ar} /{ }^{40} \mathrm{Ar}$ vs. ${ }^{39} \mathrm{Ar} /{ }^{40} \mathrm{Ar}$ ), for one of the Late Cretaceous mafic dikes (PC-01) in the SCMB. Details for each heating steps are listed in Table 1, estimated errors are at the $2 \sigma$ level. (b) Age plateau plots for 9 mafic dikes. (c) Age plateau plots for 21 rhyolites and the associated basalts in the SCMB. Letters in the parenthesis denote basalt (B) and rhyolite (R), respectively. Sample localities are listed in Table 2. 
(c) Bimodal volcanic suites and rhyolites

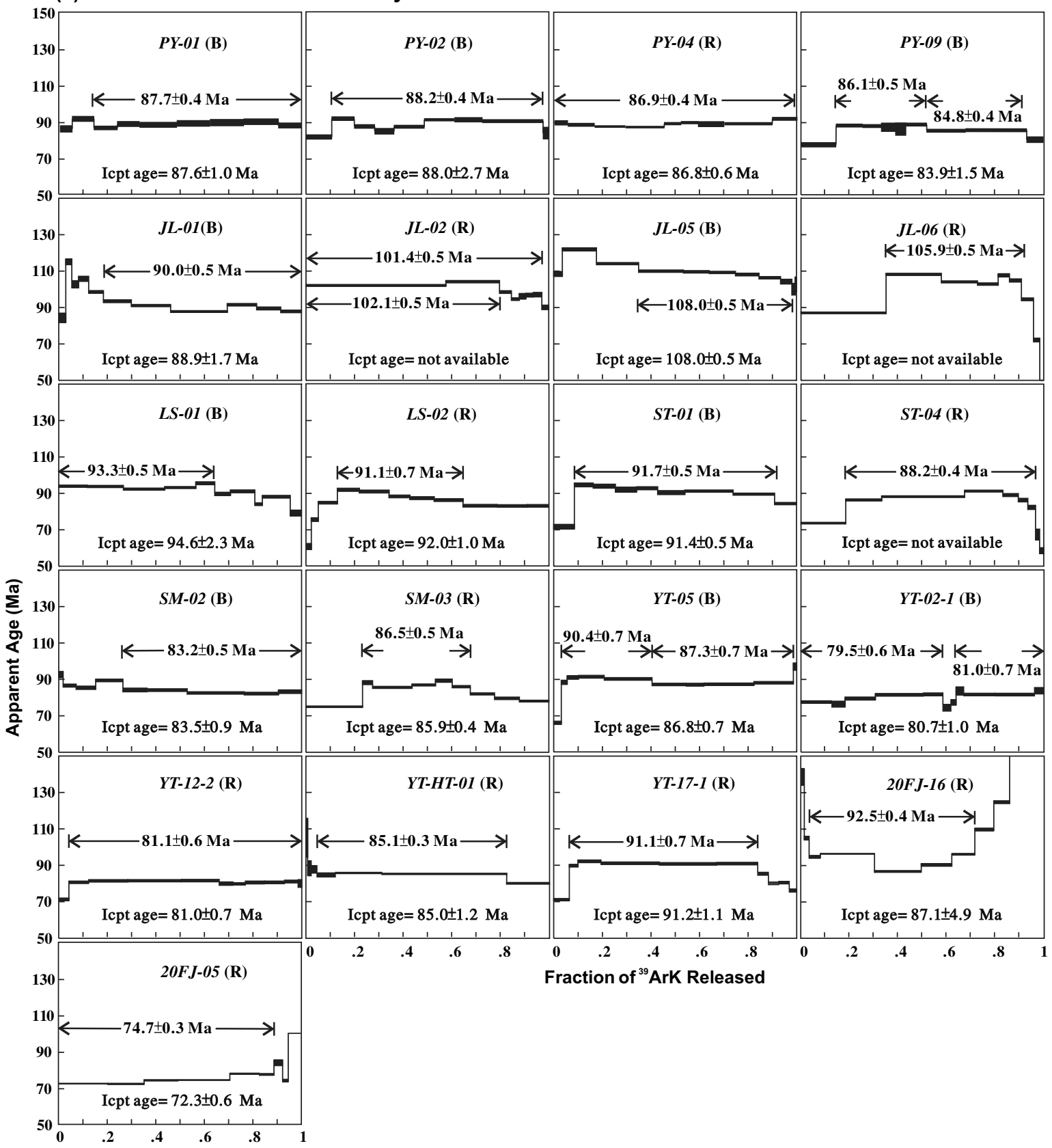

Fig. 3 (continued)

298.5. Potassium contents of the sample (measured separately with X-ray fluorescent spectrometry), ${ }^{40} \mathrm{Ar}^{*}$ $\left({ }^{40} \mathrm{Ar}\right.$ after calibration with air), percentage of air introduced ${ }^{40} \mathrm{Ar}$ and the age obtained are listed in Table 3. Age errors are derived from the expression of Roddick (1987).

Two rhyolitic rocks, one from Julipin (JL-02) and the other from Taozu (ZJ-23), have been subjected to the U$\mathrm{Pb}$ zircon age dating with an excimer LA-ICPMS at the Northwest University (Xi'an, China). The instrument used was an Elan 6100 Dynamic Reaction Cell ICPMS (Perkin Elmer/SCIEX) coupled with a GeoLas 200M laser-ablation system (MicroLas) composed of a $193 \mathrm{~nm} \mathrm{ArF-}$ excimer laser and a homogenizing, imaging optical system. Details of the analysis and parameters used were described by Yuan et al. (2004). Isotope ratios and elemental concentrations were determined for a 40-60 $\mu \mathrm{m}$ spot size using the GLITTER 4.0 software (Macquarie University), and then corrected from the external standard - Harvard zircon 91500 (Wiedenbeck et al., 1995) (Table 4). Common Pb corrections have also been carried out following the procedure of Andersen (2002). Zircon internal growth textures were documented by cathodoluminescence (CL) images taking a JEOL JSM-6360LV scanning electron microscope attached with a panchromatic CL imaging system (Gatan Mini-CL) at the Academia Sinica (Taipei). Using the 
Table 2

Summary of ${ }^{40} \mathrm{Ar} /{ }^{39} \mathrm{Ar}$ age results for bimodal volcanics and mafic dikes

\begin{tabular}{|c|c|c|c|c|c|c|c|c|}
\hline \multirow[t]{2}{*}{ Sample No. } & \multirow{2}{*}{$\begin{array}{l}\text { Sample } \\
\text { locality }\end{array}$} & \multirow{2}{*}{$\begin{array}{l}\text { Total gas age } \\
(\mathrm{Ma} \pm 1 \sigma)\end{array}$} & \multirow{2}{*}{$\begin{array}{l}\text { Plateau age } \\
(\mathrm{Ma} \pm 1 \sigma)\end{array}$} & & \multicolumn{3}{|c|}{${ }^{36} \mathrm{Ar} /{ }^{40} \mathrm{Ar}-{ }^{39} \mathrm{Ar} /{ }^{40} \mathrm{Ar}$ diagram } & \multirow{2}{*}{$\begin{array}{l}\text { Recom. } \\
\text { age }(\mathrm{Ma})^{\mathrm{a}}\end{array}$} \\
\hline & & & & & $\begin{array}{l}\text { Intercept } \\
\text { Age (Ma) }\end{array}$ & $\left({ }^{40} \mathrm{Ar} /{ }^{36} \mathrm{Ar}\right) \mathrm{i}$ & MSWD & \\
\hline \multicolumn{9}{|c|}{ Bimodal volcanics } \\
\hline PY-01(B) & Pingyen & $87.8 \pm 0.4$ & $87.7 \pm 0.4$ & $\left(700-1200{ }^{\circ} \mathrm{C}\right)$ & $87.6 \pm 1.0$ & $291 \pm 7$ & 2.0 & $87.6 \pm 1.0$ \\
\hline PY-02(B) & Pingyen & $87.1 \pm 0.4$ & $88.2 \pm 0.4$ & $\left(600-1100{ }^{\circ} \mathrm{C}\right)$ & $88.0 \pm 2.7$ & $303 \pm 8$ & 5.7 & $88.0 \pm 2.7$ \\
\hline PY-04(R) & Pingyen & $87.2 \pm 0.4$ & $86.9 \pm 0.4$ & $\left(450-1100^{\circ} \mathrm{C}\right)$ & $86.8 \pm 0.6$ & $307 \pm 4$ & 2.8 & $86.8 \pm 0.6$ \\
\hline PY-09(B) ${ }^{b}$ & Pingyen & $82.8 \pm 0.4$ & $\begin{array}{l}86.1 \pm 0.5 \\
84.8 \pm 0.4\end{array}$ & $\begin{array}{l}\left(570-900{ }^{\circ} \mathrm{C}\right) \\
\left(900-1200{ }^{\circ} \mathrm{C}\right)\end{array}$ & $83.9 \pm 1.5$ & $340 \pm 35$ & 0.9 & $83.9 \pm 1.5$ \\
\hline JL-01(B) & Julipin & $92.0 \pm 0.5$ & $90.0 \pm 0.5$ & $\left(875-1200^{\circ} \mathrm{C}\right)$ & $88.9 \pm 1.7$ & $322 \pm 13$ & 8.0 & $88.9 \pm 1.7$ \\
\hline JL-02(R) & Julipin & $101.3 \pm 0.5$ & $\begin{array}{l}102.1 \pm 0.5 \\
101.4 \pm 0.5\end{array}$ & $\begin{array}{l}\left(500-600{ }^{\circ} \mathrm{C}\right) \\
\left(500-1100^{\circ} \mathrm{C}\right)\end{array}$ & NA & & & $101.4 \pm 0.5$ \\
\hline JL-05(B) & Julipin & $111.3 \pm 0.5$ & $108.0 \pm 0.5$ & $\left(780-1070{ }^{\circ} \mathrm{C}\right)$ & $108.0 \pm 0.5$ & $729 \pm 60$ & 2.9 & $108.0 \pm 0.5$ \\
\hline JL-06(R) & Julipin & $97.6 \pm 0.5$ & $105.9 \pm 0.5$ & $\left(525-900{ }^{\circ} \mathrm{C}\right)$ & NA & & & $105.9 \pm 0.5$ \\
\hline LS-01(B) & Lientoutang & $91.5 \pm 0.5$ & $93.3 \pm 0.5$ & $\left(580-880{ }^{\circ} \mathrm{C}\right)$ & $94.6 \pm 2.3$ & $100 \pm 41$ & $>100$ & $93.3 \pm 0.5$ \\
\hline LS-02(R) & Lientoutang & $88.2 \pm 0.7$ & $91.1 \pm 0.7$ & $\left(450-720^{\circ} \mathrm{C}\right)$ & $92.0 \pm 1.0$ & 280 & 61 & $92.0 \pm 1.0$ \\
\hline ST-01(B) & Xuentandi & $89.3 \pm 0.5$ & $91.7 \pm 0.5$ & $\left(600-1100^{\circ} \mathrm{C}\right)$ & $91.4 \pm 0.5$ & $150 \pm 12$ & 1.6 & $91.7 \pm 0.5$ \\
\hline ST-04(R) & Xuentandi & $84.7 \pm 0.4$ & $88.2 \pm 0.4$ & $\left(500-1000^{\circ} \mathrm{C}\right)$ & NA & & & $88.2 \pm 0.4$ \\
\hline SM-02(B) & Shanmeng & $84.4 \pm 0.5$ & $83.2 \pm 0.5$ & $\left(880-1200^{\circ} \mathrm{C}\right)$ & $83.5 \pm 0.9$ & $259 \pm 68$ & 1.5 & $83.2 \pm 0.5$ \\
\hline SM-03(R) & Shanmeng & $81.8 \pm 0.4$ & $86.5 \pm 0.5$ & $\left(500-900{ }^{\circ} \mathrm{C}\right)$ & $85.9 \pm 0.4$ & $291 \pm 3$ & $>100$ & $85.9 \pm 0.4$ \\
\hline YT-05(B) & Yongtai & $89.2 \pm 3.5$ & $\begin{array}{l}90.4 \pm 0.7 \\
87.3 \pm 0.7\end{array}$ & $\begin{array}{l}\left(450-640{ }^{\circ} \mathrm{C}\right) \\
\left(720-1200^{\circ} \mathrm{C}\right)\end{array}$ & $86.8 \pm 0.7$ & $327 \pm 18$ & 2.6 & $86.8 \pm 0.7$ \\
\hline YT-02-1(B) & Yongtai & $81.4 \pm 0.9$ & $\begin{array}{l}79.5 \pm 0.6 \\
81.0 \pm 0.7\end{array}$ & $\begin{array}{l}\left(400-660^{\circ} \mathrm{C}\right) \\
\left(740-1200^{\circ} \mathrm{C}\right)\end{array}$ & $\begin{array}{l}81.6 \pm 1.1 \\
80.7 \pm 1.0\end{array}$ & $\begin{array}{l}245 \pm 15 \\
320 \pm 24\end{array}$ & $\begin{array}{l}5.8 \\
5.7\end{array}$ & $80.7 \pm 1.0$ \\
\hline YT-12-2(R) & Yongtai & $81.5 \pm 0.7$ & $81.1 \pm 0.6$ & $\left(450-1200^{\circ} \mathrm{C}\right)$ & $81.0 \pm 0.7$ & $319 \pm 8$ & 5.3 & $81.0 \pm 0.7$ \\
\hline YT-HT-01(R) & Yongtai & $84.6 \pm 0.3$ & $85.1 \pm 0.3$ & $\left(752-920^{\circ} \mathrm{C}\right)$ & $85.0 \pm 1.2$ & $285 \pm 3$ & 3.5 & $85.0 \pm 1.2$ \\
\hline YT-17-1(R) & Yongtai & $90.5 \pm 0.7$ & $91.1 \pm 0.7$ & $\left(450-720^{\circ} \mathrm{C}\right)$ & $91.2 \pm 1.1$ & & 7.6 & $91.1 \pm 0.7$ \\
\hline 20FJ-16(R) & Dehua & $119.5 \pm 0.7$ & $92.5 \pm 0.4$ & $\left(500-900{ }^{\circ} \mathrm{C}\right)$ & $87.1 \pm 4.9$ & $438 \pm 14$ & 11.0 & $92.5 \pm 0.4$ \\
\hline 20FJ-05(R) & Lingtonshan & $79.2 \pm 0.7$ & $74.7 \pm 0.3$ & $\left(400-900^{\circ} \mathrm{C}\right)$ & $72.3 \pm 0.6$ & $299 \pm 16$ & 1.7 & $72.3 \pm 0.6$ \\
\hline \multicolumn{9}{|l|}{ Mafic dikes } \\
\hline KM92-CK02 & Chinmen & $85.6 \pm 0.3$ & $81.9 \pm 0.3$ & $\left(620-985^{\circ} \mathrm{C}\right)$ & $82.3 \pm 0.7$ & $286 \pm 13$ & 3.8 & $82.3 \pm 0.7$ \\
\hline KM92-GT02 & Chinmen & $90.6 \pm 1.3$ & $90.5 \pm 1.3$ & $\left(610-970{ }^{\circ} \mathrm{C}\right)$ & $90.0 \pm 1.4$ & $315 \pm 10$ & 7.3 & $90.0 \pm 1.4$ \\
\hline KM92-LL05 & Chinmen & $77.8 \pm 0.3$ & $76.1 \pm 0.4$ & $\left(624-1050^{\circ} \mathrm{C}\right)$ & $76.8 \pm 2.0$ & $310 \pm 13$ & 34.6 & $76.8 \pm 2.0$ \\
\hline KM92-NS03 & Chinmen & $81.2 \pm 1.2$ & $79.8 \pm 1.1$ & $\left(669-1041^{\circ} \mathrm{C}\right)$ & $80.4 \pm 1.9$ & $299 \pm 4$ & 5.2 & $80.4 \pm 1.9$ \\
\hline FJ92-TH02 & Fuzhou & $85.6 \pm 0.3$ & $86.0 \pm 0.3$ & $\left(699-1124^{\circ} \mathrm{C}\right)$ & $86.3 \pm 0.8$ & $283 \pm 5$ & 19.9 & $86.3 \pm 0.8$ \\
\hline FJ92-KS02 & Fuzhou & $105.7 \pm 0.3$ & $93.8 \pm 0.3$ & $\left(551-1100^{\circ} \mathrm{C}\right)$ & $93.3 \pm 0.9$ & $299 \pm 5$ & 1.2 & $93.3 \pm 0.9$ \\
\hline FJ92-KS03 & Fuzhou & $93.2 \pm 0.4$ & $92.2 \pm 0.4$ & $\left(545-1121^{\circ} \mathrm{C}\right)$ & $93.0 \pm 1.2$ & $297 \pm 23$ & 10.0 & $93.0 \pm 1.2$ \\
\hline FJ92-PC01 & Fuzhou & $79.0 \pm 0.4$ & $79.4 \pm 0.4$ & $\left(542-1170^{\circ} \mathrm{C}\right)$ & $79.9 \pm 0.6$ & $292 \pm 2$ & 9.1 & $79.9 \pm 0.6$ \\
\hline FJ93-ZUD02 & Zhangzhou & $91.5 \pm 0.4$ & $82.1 \pm 0.4$ & $\left(647-1094^{\circ} \mathrm{C}\right)$ & $83.0 \pm 1.9$ & $287 \pm 11$ & 21.9 & $83.0 \pm 1.9$ \\
\hline
\end{tabular}

In bimodal volcanics, $\mathrm{B}$ and $\mathrm{R}$ denote basalt and rhyolite, respectively.

NA, not available due to clustering of data points.

${ }^{\mathrm{a}}$ The intercept (Icpt) age is adopted when the initial ${ }^{40} \mathrm{Ar} /{ }^{36} \mathrm{Ar}$ is within the range of $280-360$; otherwise the plateau age is taken.

${ }^{b}$ A basaltic dike penetrating rhyolite lavas. 
Table 3

$\mathrm{K}-\mathrm{Ar}$ age results for mafic dikes

\begin{tabular}{|c|c|c|c|c|c|}
\hline Sample No. & Sample locality & $\mathrm{K}( \pm 1 \sigma)(\%)$ & $\begin{array}{l}{ }^{40} \mathrm{Ar}^{\mathrm{a}}( \pm 1 \sigma) \\
\left(\times 10^{-8} \mathrm{ccSTP} / \mathrm{g}\right)\end{array}$ & $\begin{array}{l}\text { Atmos. } \\
\text { Ar }(\%)\end{array}$ & $\begin{array}{l}\text { Age }( \pm 1 \sigma) \\
(\mathrm{Ma})\end{array}$ \\
\hline KM92-GG03 & Chinmen & $1.63 \pm 0.03$ & $588 \pm 6$ & 8.7 & $90.7 \pm 2.0$ \\
\hline KM92-M08 & Chinmen & $1.32 \pm 0.03$ & $457 \pm 5$ & 7.3 & $87.1 \pm 1.9^{\mathrm{a}}$ \\
\hline KM92-M08 & Chinmen & $1.32 \pm 0.03$ & $448 \pm 5$ & 3.8 & $85.3 \pm 2.0$ \\
\hline KM92-HS03 & Lieyu & $1.47 \pm 0.03$ & $527 \pm 6$ & 11.8 & $90.4 \pm 2.0$ \\
\hline KM92-TK01 & Lieyu & $1.38 \pm 0.03$ & $473 \pm 5$ & 12.6 & $86.3 \pm 1.9$ \\
\hline MA-02 & Matsu & $1.60 \pm 0.02$ & $578 \pm 6$ & 4.1 & $90.4 \pm 2.0$ \\
\hline MA-10 & Matsu & $2.94 \pm 0.05$ & $110 \pm 1$ & 5.1 & $93.7 \pm 2.1$ \\
\hline MA-20-1 & Matsu & $1.29 \pm 0.01$ & $394 \pm 4$ & 7.8 & $79.8 \pm 1.8$ \\
\hline MAS-08 & Matsu & $2.01 \pm 0.03$ & $675 \pm 7$ & 4.2 & $84.8 \pm 1.9$ \\
\hline MAS-09 & Matsu & $1.57 \pm 0.01$ & $553 \pm 5$ & 6.0 & $89.9 \pm 2.0$ \\
\hline MAS-17 & Matsu & $1.65 \pm 0.02$ & $620 \pm 6$ & 2.6 & $92.1 \pm 2.1$ \\
\hline FJ92-KS03 & Fuzhou & $1.77 \pm 0.03$ & $631 \pm 7$ & 3.9 & $89.6 \pm 2.0$ \\
\hline
\end{tabular}

${ }^{\text {a }}$ Determined by Prof. Y. Tatsumi (Kyoto University, now at JAMSTEC).

ISOPLOT (rev. 2.49) program (Ludwig, 2001), apparent ages for each spot of analysis were calculated (Table 4) and ${ }^{206} \mathrm{~Pb} /{ }^{238} \mathrm{U}$ vs. ${ }^{207} \mathrm{~Pb} /{ }^{235} \mathrm{U}$ concordia diagrams, incorporated with some representative zircon CL images, were depicted (Fig. 4a and b).

Major and trace element abundances and $\mathrm{Sr}, \mathrm{Nd}$ and $\mathrm{Pb}$ isotope ratios for bimodal volcanics and mafic dikes have been measured. Analytical procedures, except $\mathrm{Pb}$ isotope compositions, follow those described by Chen et al. (2000). Here we particularly focus the use of major element data to reveal aluminosity of the studied rhyolites (Table 5). Trace element and isotope results will be reported elsewhere.

\section{Results of age dating}

4.1. ${ }^{40}$ Ar/ ${ }^{39}$ Ar ages

Generally, ${ }^{40} \mathrm{Ar} /{ }^{39} \mathrm{Ar}$ ages for each rhyolite and basalt pair of bimodal suites in Zhejiang are rather consistent, except one of the Julipin pairs in the Tientai area where rhyolite sample JL-02 is $101.4 \pm 0.5 \mathrm{Ma}$ and the associated basalt (JL-01) is $88.9 \pm 1.7 \mathrm{Ma}$. Another pair in Julipin yields more consistent results: rhyolite sample JL-06 is $105.9 \pm 0.5 \mathrm{Ma}$ and basalt (JL-05) is $108.0 \pm 0.5 \mathrm{Ma}$ (Fig. 3c). The decoupled younger age of basalt sample JL01 is suggested to be of a sill origin, as sills $(<97 \mathrm{Ma})$ are commonly observed in the volcanic sequence of the Ningbo Basin to the north (Lapierre et al., 1997). On the other hand, Lientoutang of the Tientai area gives $93.3 \pm 0.5 \mathrm{Ma}$ for rhyolite (LS-02) and 92.0 \pm 1.0 Ma for basalt (LS-01). Traditionally, Julipin volcanics were correlated to the uppermost formation of the lower volcanic sequence of $\mathrm{N}$ Zhejiang (BGMRZJ, 1989). Our age data provide another thought that Julipin volcanics could have formed at the transitional to the earliest stage for the upper series. This will be discussed in conjunction with chemical data.

The bimodal suite of Xuentandi in the Ningbo Basin is dated as $91.7 \pm 0.5 \mathrm{Ma}$ for basalt (ST-01) and 88.2 \pm $0.4 \mathrm{Ma}$ for rhyolite (ST-04). Previously, ages adopted for early eruptions of rhyolite in the Ningbo Basin were $101 \mathrm{Ma}$ based on the contact relationship to the Liangnong granite and two younger ages $(97.0 \pm 4.3$ and $93.8 \pm 1.1 \mathrm{Ma}$ ) for rhyolites ( $\mathrm{Yu}$ et al., 1993). Since our rhyolite age is obtained from direct measurement on the sample collected in the upper level (Fig. 2), hence, a time span of 101-88 Ma is suggested for the Xuentandi volcanics by taking the field observation into account.

As for Pingyen samples (prefixed with PY-), ages of two basalt inclusions $(87.6 \pm 1.0$ and $88.0 \pm 2.7 \mathrm{Ma})$ are in agreement with the age of their rhyolite host $(86.8 \pm 0.6 \mathrm{Ma})$, whereas the age of basaltic dike is slightly younger $(83.9 \pm 1.5 \mathrm{Ma})$. These results, along with the shape of inclusions, indicate the possibility of injection of basaltic magma into the rhyolitic magma chamber to trigger eruption (Nairn et al., 2006). They were later intruded by the basaltic dike after solidification. Further to S Zhejiang, bimodal suite in the Shanmeng Basin shows slightly younger ages than other suites: $85.9 \pm 0.5 \mathrm{Ma}$ for the rhyolite (SM-03) and $83.2 \pm 0.5 \mathrm{Ma}$ for the basalt (SM-02).

In Fujian, ages for volcanic rocks of the YongtaiDehua area, the largest volcanic basin in the SCMB, span a range from $92.5 \pm 0.4 \mathrm{Ma}$ to $80.7 \pm 1.0 \mathrm{Ma}$ based on 6 analyses (including the neighboring small body of Huangtang rhyolite). The total time span for volcanic activities bracketed by the lowermost and uppermost Yongtai rhyolites is $91-81 \mathrm{Ma}$ (Fig. 2), rendering the young age for the lowermost basalt $(80.7 \pm 1.0 \mathrm{Ma})$ unrealistic. Judging from the fact that mafic dike injection is a common feature in the strata unconformably underlying the Yongtai volcanics (i.e., the Nanyuan Formation), a mafic dike that penetrated the thick basalt layer making it indistinguishable from the host rock is tentatively explained for this sample. Our results also differ from the previous view that the Dehu volcanics are significantly younger than the Yongtai volcanics (Fong et al., 1991), they might have erupted simultaneously.

An even younger age of silicic eruption is presented by the Lingtongshan rhyolite $(72.3 \pm 0.6 \mathrm{Ma})$ further south. 
Table 4

$\mathrm{U}-\mathrm{Pb}$ zircon age results for two rhyolitic rocks

\begin{tabular}{|c|c|c|c|c|c|c|c|c|c|c|c|c|}
\hline \multirow[t]{2}{*}{ No. } & \multicolumn{6}{|c|}{ Ratios (common-Pb corrected) } & \multicolumn{6}{|c|}{ Ages (common-Pb Corrected, Ma) } \\
\hline & ${ }^{207} \mathrm{~Pb} /{ }^{235} \mathrm{U}$ & $1 \sigma$ & ${ }^{206} \mathrm{~Pb} /{ }^{238} \mathrm{U}$ & $1 \sigma$ & ${ }^{208} \mathrm{~Pb} /{ }^{232} \mathrm{Th}$ & $1 \sigma$ & ${ }^{207} \mathrm{~Pb} /{ }^{235} \mathrm{U}$ & $1 \sigma$ & ${ }^{206} \mathrm{~Pb} /{ }^{238} \mathrm{U}$ & $1 \sigma$ & ${ }^{208} \mathrm{~Pb} /{ }^{232} \mathrm{Th}$ & $1 \sigma$ \\
\hline \multicolumn{13}{|c|}{ Julipin rhyolite (JL-02) } \\
\hline 1 & 0.49262 & 0.00425 & 0.06460 & 0.00056 & 0.02012 & 0.00010 & 407 & 5.8 & 404 & 12 & 403 & 4.1 \\
\hline 2 & 0.28587 & 0.00246 & 0.03518 & 0.0003 & 0.01234 & 0.00006 & 255 & 3.9 & 223 & 3.8 & 248 & 2.5 \\
\hline 3 & 0.27427 & 0.00249 & 0.03574 & 0.00031 & 0.01081 & 0.00006 & 246 & 4.0 & 226 & 3.8 & 217 & 2.3 \\
\hline 4 & 0.21204 & 0.00182 & 0.02882 & 0.00025 & 0.00928 & 0.00005 & 195 & 3.0 & 183 & 3.1 & 187 & 1.9 \\
\hline 5 & 0.19922 & 0.0017 & 0.02886 & 0.00025 & 0.01033 & 0.00005 & 185 & 2.9 & 183 & 3.1 & 208 & 2.1 \\
\hline 6 & 0.20543 & 0.00178 & 0.02875 & 0.00026 & 0.01052 & 0.00005 & 190 & 3.0 & 183 & 3.2 & 212 & 2.2 \\
\hline 7 & 0.14241 & 0.00129 & 0.02091 & 0.00018 & 0.00664 & 0.00003 & 135 & 2.3 & 133 & 2.3 & 134 & 1.4 \\
\hline 8 & 0.17890 & 0.00155 & 0.01972 & 0.00017 & 0.00734 & 0.00004 & 167 & 2.7 & 126 & 2.2 & 148 & 1.5 \\
\hline 9 & 0.14826 & 0.00135 & 0.02045 & 0.00018 & 0.00630 & 0.00003 & 140 & 2.4 & 131 & 2.3 & 127 & 1.3 \\
\hline 10 & 0.16663 & 0.00144 & 0.02041 & 0.00018 & 0.00760 & 0.00004 & 157 & 2.5 & 130 & 2.3 & 153 & 1.6 \\
\hline 11 & 0.12623 & 0.00109 & 0.01592 & 0.00014 & 0.00571 & 0.00003 & 121 & 2.0 & 102 & 1.8 & 115 & 1.2 \\
\hline 12 & 0.24120 & 0.00207 & 0.01674 & 0.00015 & 0.00767 & 0.00004 & 219 & 3.4 & 107 & 1.9 & 155 & 1.6 \\
\hline 13 & 0.10553 & 0.00092 & 0.01621 & 0.00014 & 0.00539 & 0.00003 & 102 & 1.7 & 104 & 1.8 & 109 & 1.1 \\
\hline 14 & 0.11834 & 0.00102 & 0.01607 & 0.00014 & 0.00525 & 0.00003 & 114 & 1.8 & 103 & 1.8 & 106 & 1.1 \\
\hline 15 & 0.10763 & 0.00098 & 0.01509 & 0.00013 & 0.00496 & 0.00003 & 104 & 1.8 & 97 & 1.7 & 100 & 1.1 \\
\hline 16 & 0.12531 & 0.00108 & 0.01582 & 0.00014 & 0.00514 & 0.00003 & 120 & 1.9 & 101 & 1.8 & 104 & 1.1 \\
\hline 17 & 0.10701 & 0.00093 & 0.01588 & 0.00014 & 0.00526 & 0.00003 & 103 & 1.7 & 102 & 1.8 & 106 & 1.1 \\
\hline 18 & 0.13090 & 0.00114 & 0.01572 & 0.00014 & 0.00504 & 0.00003 & 125 & 2.0 & 101 & 1.8 & 102 & 1.0 \\
\hline 19 & 0.11913 & 0.00104 & 0.01559 & 0.00014 & 0.00558 & 0.00003 & 114 & 1.9 & 100 & 1.8 & 113 & 1.2 \\
\hline 20 & 0.11871 & 0.00103 & 0.01569 & 0.00014 & 0.00553 & 0.00003 & 114 & 1.9 & 100 & 1.8 & 111 & 1.1 \\
\hline 21 & 0.11958 & 0.00105 & 0.01160 & 0.00010 & 0.00418 & 0.00002 & 115 & 1.9 & 74 & 1.3 & 84 & 0.9 \\
\hline 22 & 0.27192 & 0.00232 & 0.02218 & 0.00019 & 0.01025 & 0.00005 & 244 & 3.7 & 141 & 2.4 & 206 & 2.1 \\
\hline 23 & 0.24503 & 0.00211 & 0.01679 & 0.00015 & 0.00622 & 0.00003 & 223 & 3.4 & 107 & 1.9 & 125 & 1.3 \\
\hline 24 & 0.30109 & 0.00260 & 0.01705 & 0.00015 & 0.00776 & 0.00004 & 267 & 4.1 & 109 & 8.1 & 156 & 1.6 \\
\hline 25 & 4.21667 & 0.03565 & 0.27246 & 0.00237 & 0.08926 & 0.00045 & 1677 & 14 & 1562 & 28 & 1728 & 17 \\
\hline 26 & 33.89499 & 0.28665 & 0.31221 & 0.00270 & 0.80703 & 0.00409 & 3607 & 17 & 1752 & 33 & & 92 \\
\hline 27 & 20.77231 & 0.17916 & 0.19409 & 0.00173 & 0.00966 & 0.00005 & 3128 & 17 & 1144 & 33 & 194 & 2.0 \\
\hline 28 & 3.00957 & 0.02590 & 0.04084 & 0.00035 & 0.08682 & 0.00045 & 1410 & 13 & 258 & 26 & 1683 & 17 \\
\hline 29 & 0.68973 & 0.00589 & 0.02189 & 0.00019 & 0.01708 & 0.00009 & 533 & 7.1 & 140 & 14 & 342 & 3.5 \\
\hline 30 & 0.60353 & 0.00510 & 0.02605 & 0.00022 & 0.03715 & 0.00019 & 480 & 6.5 & 166 & 13 & 737 & 7.4 \\
\hline \multicolumn{13}{|c|}{ Taozu rhyolite (ZJ-23) } \\
\hline 1 & 0.09140 & 0.00091 & 0.04023 & 0.00035 & 0.00446 & 0.00002 & 89 & 0.8 & 254 & 2 & 90 & 0.4 \\
\hline 2 & 0.34366 & 0.23684 & 0.01625 & 0.00176 & 0.00455 & 0.00061 & 300 & 179 & 104 & 11 & 92 & 12 \\
\hline 3 & 0.09035 & 0.00311 & 0.01423 & 0.00013 & 0.00517 & 0.00009 & 88 & 3 & 91 & 0.8 & 104 & 2 \\
\hline 4 & 0.08951 & 0.00252 & 0.01364 & 0.00013 & 0.00433 & 0.00003 & 87 & 2 & 87 & 0.8 & 87 & 0.7 \\
\hline 5 & 0.09312 & 0.00265 & 0.01366 & 0.00013 & 0.00432 & 0.00003 & 90 & 2 & 88 & 0.8 & 87 & 0.7 \\
\hline 6 & 0.09211 & 0.00088 & 0.01391 & 0.00012 & 0.00448 & 0.00002 & 90 & 0.8 & 89 & 0.8 & 90 & 0.4 \\
\hline 7 & 0.07573 & 0.00188 & 0.01193 & 0.00011 & 0.00482 & 0.00006 & 74 & 2 & 76 & 0.7 & 97 & 1 \\
\hline 8 & 0.09392 & 0.00086 & 0.01342 & 0.00012 & 0.00426 & 0.00002 & 91 & 0.8 & 86 & 0.8 & 86 & 0.4 \\
\hline 9 & 0.08217 & 0.00072 & 0.01180 & 0.00010 & 0.00392 & 0.00002 & 80 & 0.7 & 76 & 0.6 & 79 & 0.4 \\
\hline 10 & 0.07685 & 0.00067 & 0.01156 & 0.00010 & 0.00367 & 0.00002 & 75 & 0.6 & 74 & 0.6 & 74 & 0.4 \\
\hline 11 & 0.08574 & 0.00076 & 0.01213 & 0.00011 & 0.00469 & 0.00003 & 84 & 0.7 & 78 & 0.7 & 95 & 0.6 \\
\hline 12 & 0.14579 & 0.00141 & 0.01489 & 0.00013 & 0.00572 & 0.00003 & 138 & 1 & 95 & 0.8 & 115 & 0.6 \\
\hline 13 & 0.08869 & 0.00252 & 0.01397 & 0.00012 & 0.00470 & 0.00006 & 86 & 2 & 89 & 0.8 & 95 & 1 \\
\hline 14 & 0.17677 & 0.00158 & 0.01426 & 0.00013 & 0.00621 & 0.00003 & 165 & 1 & 91 & 0.8 & 125 & 0.6 \\
\hline 15 & 0.08795 & 0.00264 & 0.01385 & 0.00012 & 0.00460 & 0.00009 & 86 & 2 & 89 & 0.8 & 93 & 2 \\
\hline 16 & 0.08310 & 0.00074 & 0.01181 & 0.00010 & 0.00443 & 0.00002 & 81 & 0.7 & 76 & 0.6 & 89 & 0.4 \\
\hline 17 & 0.17045 & 0.00299 & 0.01361 & 0.00013 & 0.00401 & 0.00004 & 160 & 3 & 87 & 0.8 & 81 & 0.7 \\
\hline 18 & 0.08560 & 0.00076 & 0.01183 & 0.00010 & 0.00414 & 0.00002 & 83 & 0.7 & 76 & 0.6 & 84 & 0.4 \\
\hline 19 & 0.08615 & 0.00077 & 0.01285 & 0.00011 & 0.00443 & 0.00002 & 84 & 0.7 & 82 & 0.7 & 89 & 0.4 \\
\hline 20 & 0.11021 & 0.00096 & 0.01222 & 0.00011 & 0.00435 & 0.00002 & 106 & 0.9 & 78 & 0.7 & 88 & 0.4 \\
\hline 21 & 0.08713 & 0.00332 & 0.01372 & 0.00013 & 0.00480 & 0.00012 & 85 & 3 & 88 & 0.8 & 97 & 2 \\
\hline 22 & 0.09015 & 0.00234 & 0.01420 & 0.00012 & 0.62548 & 0.00330 & 88 & 2 & 91 & 0.8 & 9819 & 41 \\
\hline 23 & 0.07504 & 0.00224 & 0.01182 & 0.00010 & 0.00497 & 0.00009 & 73 & 2 & 76 & 0.7 & 100 & 2 \\
\hline 24 & 0.10390 & 0.00930 & 0.01303 & 0.00012 & 0.00527 & 0.00003 & 100 & 0.9 & 84 & 0.8 & 106 & 0.6 \\
\hline 25 & 0.08660 & 0.00079 & 0.01338 & 0.00012 & 0.00483 & 0.00003 & 84 & 0.7 & 86 & 0.8 & 97 & 0.6 \\
\hline
\end{tabular}

Conclusively, all these ${ }^{40} \mathrm{Ar} /{ }^{39} \mathrm{Ar}$ age data indicate that rhyolite-dominated volcanic activities first took place in northern part of the SCMB at the same time as A-type granite forming stage (100-90 Ma) of the entire belt. There is a tendency that such activities had extended to younger times (90-72 Ma) in southern part of the SCMB. As for 
${ }^{40} \mathrm{Ar} /{ }^{39} \mathrm{Ar}$ ages of mafic dikes, dated as $93.3 \pm 0.9$ to $76.8 \pm 2.0 \mathrm{Ma}$ (Fig. 3b), they are considered in combination with results of the $\mathrm{K} / \mathrm{Ar}$ age.

\section{2. $K-$ Ar ages}

On the basis of small differences between the total gas age and plateau age for most of the mafic dikes in the ${ }^{40} \mathrm{Ar} /{ }^{39} \mathrm{Ar}$ dating system (Table 2), $\mathrm{K}-\mathrm{Ar}$ dating results are considered to be applicable for such rocks. Reproduced analysis of sample KM-92M08 gives a result of $87.1 \pm 1.9 \mathrm{Ma}$ (conducted at Kyoto University), which is consistent with $85.3 \pm 2.0 \mathrm{Ma}$ (this study) in the range of analytical errors. Comparison of age results on sample
FJ92-KS03 shows only a small difference between the $\mathrm{K}-\mathrm{Ar}$ age $(89.6 \pm 2.0 \mathrm{Ma})$ and the ${ }^{40} \mathrm{Ar} /{ }^{39} \mathrm{Ar}$ age $(93.0 \pm$ 1.2 Ma). $\mathrm{K}-\mathrm{Ar}$ ages for 9 samples reveal a range from $94.7 \pm 2.1$ to $79.8 \pm 1.8 \mathrm{Ma}$, similar to the ${ }^{40} \mathrm{Ar} /{ }^{39} \mathrm{Ar}$ ages. Combining all the ${ }^{40} \mathrm{Ar} /{ }^{39} \mathrm{Ar}$ and $\mathrm{K} / \mathrm{Ar}$ ages for a total of 20 mafic dike samples (Tables 2 and 3), eight are 94 $90 \mathrm{Ma}$, five are 90-85 Ma, four are 85-80 Ma and three are $80-77 \mathrm{Ma}$. It is noted that two samples from the Fuzhou Igneous Complex, FJ92-KS02 and -KS03, have similar ages of $\sim 93 \mathrm{Ma}$. Thus early mafic dike injection of the Fuzhou Igneous Complex is coeval with the magma emplacement of the adjacent Kuiqi A-type granite (Martin et al., 1994; Chen et al., 2000). This probably can register a near surface bimodal suite in southern part of the SCMB.

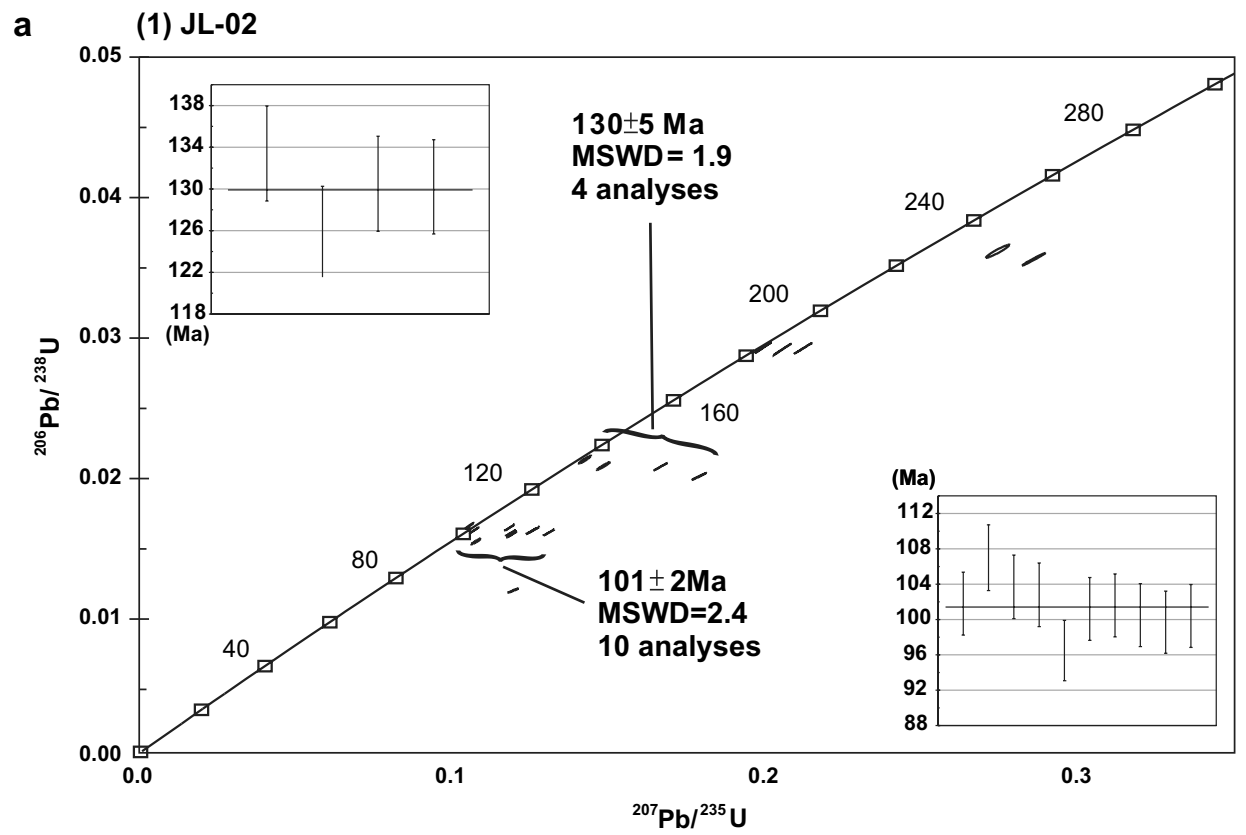

(2) JL02-2 (223Ma)

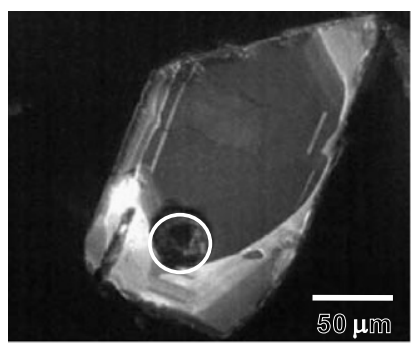

(4) JL02-8 (126Ma)

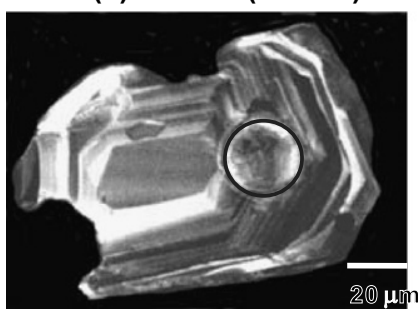

(3) JL02-7 (133Ma)

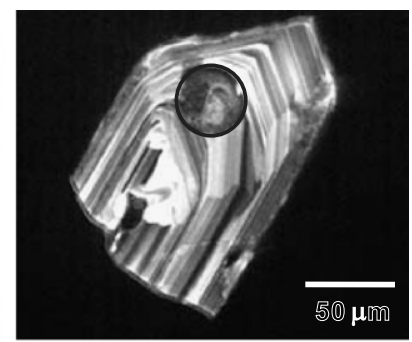

(5) JL02-17 (102Ma)

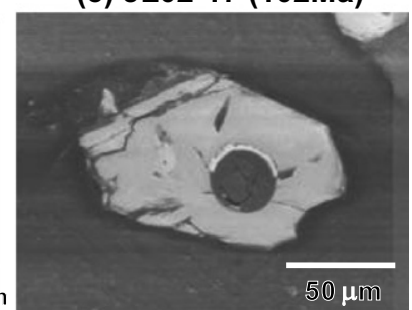

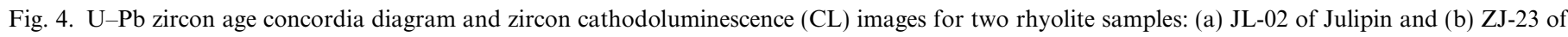

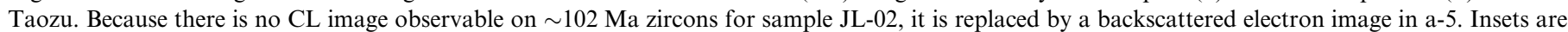
the two most significant age frequencies in each sample. 


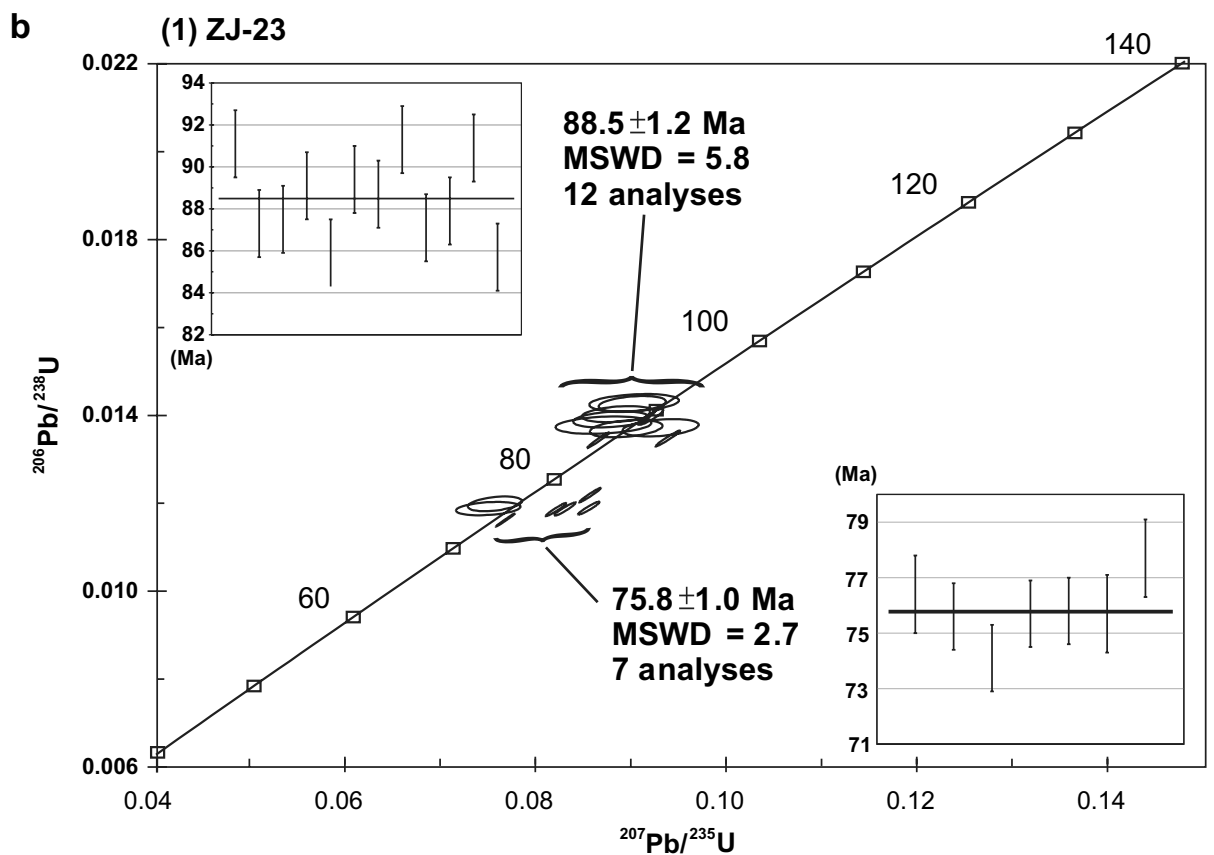

(2) ZJ23-03 (91Ma)

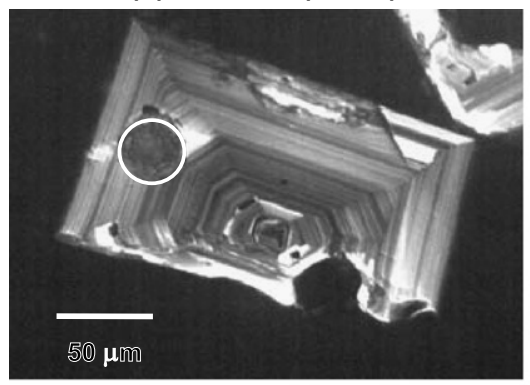

(4) ZJ23-19 (82Ma)

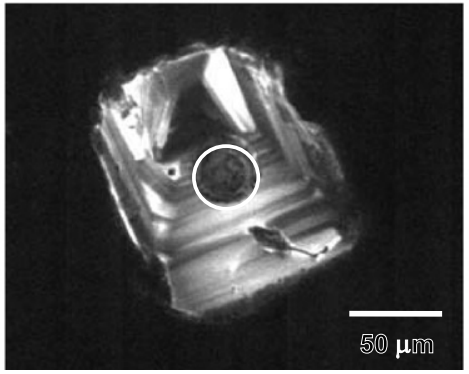

(3) ZJ23-05 (88Ma)

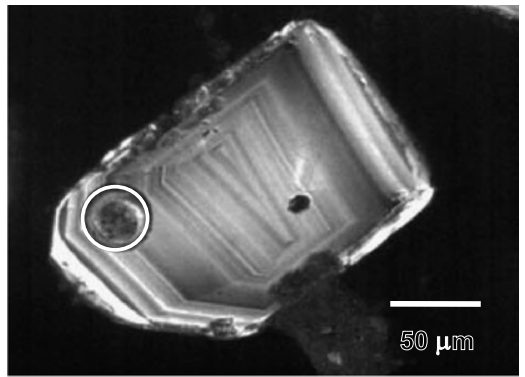

(5) ZJ23-07 (76Ma)

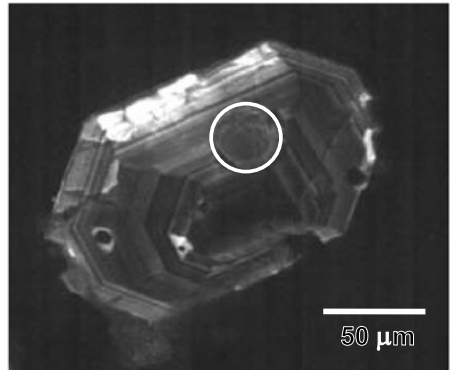

Fig. 4 (continued)

\section{3. $U-P b$ zircon and other ages}

Common problems of $\mathrm{Pb}$ loss and crystal inheritance can result in scattering of $\mathrm{U}-\mathrm{Pb}$ zircon ages (Fig. 4). One similar case dating the Late Paleozoic extension-related silicic rocks in the northern New England Fold Belt yielded widened ${ }^{207} \mathrm{~Pb} /{ }^{235} \mathrm{U}$ ages (Bryan et al., 2004). These authors used filtering procedures to confirm the ${ }^{206} \mathrm{~Pb} /{ }^{238} \mathrm{U}$ ages of $\sim 360-350 \mathrm{Ma}$ rhyolites, although they concluded that such zircons cannot provide robust age constraints due to slight $\mathrm{Pb}$ loss. The filtering criteria set by these authors are used to finalize weighted mean ${ }^{206} \mathrm{~Pb} /{ }^{238} \mathrm{U}$ ages in this study.

A total number of 30 zircon grains in sample JL-02 provide a wide spectrum of $\mathrm{U}-\mathrm{Pb}$ age ranging from $\sim 1750$ to $\sim 100 \mathrm{Ma}$ (Table 4). Among them, 10 analyses can define a significant young $\mathrm{U}-\mathrm{Pb}$ zircon age of $101 \pm 1 \mathrm{Ma}$ (Fig. 4a1). Consistency between this age and the ${ }^{40} \mathrm{Ar} /{ }^{39} \mathrm{Ar}$ whole-rock age $(101.4 \pm 0.5 \mathrm{Ma})$ not only suggests that this is the eruption age, but also supports the applicability of the ${ }^{40} \mathrm{Ar} /{ }^{39} \mathrm{Ar}$ dating method on the studied rhyolitic rocks. In addition, 4 analyses yield an age of $130 \pm 5 \mathrm{Ma}$, corre- 
sponding to the age range of the lower volcanic series. CL images reveal three types of zircon in this sample: the $\sim 101 \mathrm{Ma}$ zircons do not show observable zoning, the $\sim 130 \mathrm{Ma}$ zircons have strong zoning without an obvious core, and zircons older than 220 Ma generally display a rounded core (Fig. 4a2-5).

On the basis of 25 grain analyses, sample ZJ-23 of Tao$\mathrm{zu}$ yields two significant $\mathrm{U}-\mathrm{Pb}$ zircon ages: $88.5 \pm 1.2 \mathrm{Ma}$ $(n=12)$ and $75.8 \pm 1.0 \mathrm{Ma}(n=7)$, and the rest are basically discordant (Fig. 4b1). CL images show indistinguishable zoning patterns for zircon grains pertaining these two ages (Fig. 4b2-5). We interpret that $75.8 \mathrm{Ma}$ is the formation time of rhyolite and the single inherited age group of $88.5 \mathrm{Ma}$ indicates a cluster of zircons derived from mono-lithologic sources, most probably the silicic volcanic rocks of the upper series widespread in $\mathrm{N}$ Zhejiang (this study). Unlike JL-02, the general lack of zircons with inherited cores reflects different sources.

More evidences indicating Late Cretaceous rhyolitic eruptions in the SCMB are the CHIME monazite ages (90-80 Ma) obtained from Miocene river channel deposits in Fujian (Chen et al., 2006). Because many rhyolitic rocks in the Yongtai-Dehua Basin show obvious Ce negative anomalies (our unpublished data) - a sign of monazite fractionation, these ages reflect the time of monazites originally crystallized from such rhyolites and later subjected to deposition due to weathering. Therefore, it can be summarized from all the dating data that in the entire SCMB there had been a stage of rhyolitic eruption during 101-72 Ma, and basaltic activities (94-77 Ma) were also prevailing in this time interval. Onset of such rhyolite-dominating eruptions seems to be earlier in Zhejiang (101 Ma) than in Fujian (93 Ma).

\section{Compositions of A-type granites versus SP and P-MP rhyolites}

Fractionated I-type felsic granitoids $\left(\mathrm{SiO}_{2}>70 \%\right)$ and A-type granites in the SCMB are used to compare with the studied rhyolites for unraveling chemical characters of silicic magmas. These two types of silicic plutonic rocks can be distinguished in terms of ASI (alumina saturation

Table 5A

Chemical compositions of rhyolitic rocks in the SCMB

\begin{tabular}{|c|c|c|c|c|c|c|c|c|}
\hline $\begin{array}{l}\text { Sample } \\
\text { Age (Ma) } \\
\text { Locality }\end{array}$ & $\begin{array}{l}\text { PY-04 } \\
86.8 \pm 0.6 \\
\text { Pingyen }\end{array}$ & Pingyen & $\begin{array}{l}\text { PY-10 } \\
\text { Pingyen }\end{array}$ & $\begin{array}{l}\text { ZJ-23 } \\
75.8 \pm 1.0 \\
\text { Taozu }\end{array}$ & $\begin{array}{l}\text { JL-02 } \\
101.4 \pm 0.5 \\
\text { Julipin }\end{array}$ & $\begin{array}{l}\text { LS-02 } \\
92.0 \pm 1.0 \\
\text { Lientoutang }\end{array}$ & $\begin{array}{l}\text { ST-04 } \\
88.2 \pm 0.4 \\
\text { Xuentandi }\end{array}$ & $\begin{array}{l}\text { ST-05 } \\
\text { Xuentandi }\end{array}$ \\
\hline \multicolumn{9}{|l|}{$\mathrm{Wt} \%$} \\
\hline $\mathrm{SiO}_{2}$ & 74.96 & 74.11 & 78.42 & 77.28 & 77.31 & 72.74 & 69.98 & 70.63 \\
\hline $\mathrm{TiO}_{2}$ & 0.21 & 0.23 & 0.11 & 0.16 & 0.07 & 0.30 & 0.53 & 0.57 \\
\hline $\mathrm{Al}_{2} \mathrm{O}_{3}$ & 13.80 & 13.58 & 12.38 & 12.32 & 13.28 & 14.86 & 15.31 & 15.53 \\
\hline $\mathrm{Fe}_{2} \mathrm{O}_{3}$ & 1.26 & 1.67 & 0.72 & 0.94 & 1.06 & 1.37 & 2.12 & 2.20 \\
\hline $\mathrm{MnO}$ & 0.06 & 0.09 & 0.05 & 0.05 & 0.02 & 0.04 & 0.06 & 0.04 \\
\hline $\mathrm{MgO}$ & 0.15 & 0.36 & 0.25 & 0.00 & 0.00 & 0.03 & 0.41 & 0.20 \\
\hline $\mathrm{CaO}$ & 0.70 & 0.77 & 0.47 & 0.26 & 0.19 & 0.42 & 0.97 & 0.38 \\
\hline $\mathrm{Na}_{2} \mathrm{O}$ & 4.38 & 4.06 & 3.01 & 3.36 & 1.73 & 3.56 & 2.84 & 4.24 \\
\hline $\mathrm{K}_{2} \mathrm{O}$ & 4.26 & 4.42 & 4.66 & 4.53 & 5.04 & 6.09 & 6.15 & 4.89 \\
\hline $\mathrm{P}_{2} \mathrm{O}_{5}$ & 0.07 & 0.07 & 0.03 & 0.00 & 0.03 & 0.04 & 0.10 & 0.11 \\
\hline LOI & 0.50 & 0.17 & 0.76 & & 1.12 & 0.51 & 1.75 & 0.64 \\
\hline Total & 100.35 & 99.53 & 100.86 & 98.90 & 99.85 & 99.96 & 100.22 & 99.43 \\
\hline ASI & 1.05 & 1.06 & 1.14 & 1.13 & 1.54 & 1.13 & 1.17 & 1.20 \\
\hline $\mathrm{A} / \mathrm{NK}$ & 1.17 & 1.18 & 1.24 & 1.18 & 1.60 & 1.19 & 1.35 & 1.27 \\
\hline Sample & SM-03 & YT-17-1 & YT-08 & YT-13-1 & YT-12-2 & $20 \mathrm{FJ}-16$ & YT-HT-01 & $20 \mathrm{FJ}-05$ \\
\hline Age (Ma) & $85.9 \pm 0.4$ & $91.1 \pm 0.7$ & & & $81.0 \pm 0.7$ & $92.5 \pm 0.4$ & $85.0 \pm 1.2$ & $72.3 \pm 0.6$ \\
\hline Locality & Shanmeng & Yongtai & Yongtai & Yongtai & Yongtai & Dehua & Huangtang & Lingtonshan \\
\hline \multicolumn{9}{|l|}{$\overline{\mathrm{Wt}} \%$} \\
\hline $\mathrm{SiO}_{2}$ & 75.86 & 75.57 & 75.89 & 74.54 & 77.07 & 74.04 & 75.59 & 77.76 \\
\hline $\mathrm{TiO}_{2}$ & 0.14 & 0.22 & 0.12 & 0.13 & 0.13 & 0.30 & 0.17 & 0.12 \\
\hline $\mathrm{Al}_{2} \mathrm{O}_{3}$ & 14.57 & 12.70 & 12.47 & 11.67 & 12.45 & 14.60 & 12.86 & 11.33 \\
\hline $\mathrm{Fe}_{2} \mathrm{O}_{3}$ & 0.87 & 2.07 & 1.58 & 1.66 & 1.68 & 2.00 & 1.77 & 0.71 \\
\hline $\mathrm{MnO}$ & 0.09 & 0.13 & 0.04 & 0.09 & 0.06 & 0.03 & 0.10 & 0.03 \\
\hline $\mathrm{MgO}$ & 0.00 & 0.11 & 0.14 & 0.05 & 0.07 & 0.00 & 0.00 & 0.00 \\
\hline $\mathrm{CaO}$ & 0.47 & 0.14 & 0.32 & 0.31 & 0.10 & 0.18 & 0.44 & 0.61 \\
\hline $\mathrm{Na}_{2} \mathrm{O}$ & 3.43 & 3.20 & 1.39 & 4.11 & 3.77 & 2.72 & 4.39 & 3.59 \\
\hline $\mathrm{K}_{2} \mathrm{O}$ & 4.87 & 5.17 & 5.27 & 4.63 & 4.60 & 5.30 & 4.84 & 3.74 \\
\hline $\mathrm{P}_{2} \mathrm{O}_{5}$ & 0.03 & 0.02 & 0.01 & 0.00 & 0.00 & 0.05 & 0.04 & 0.05 \\
\hline LOI & 0.94 & 0.65 & 1.65 & 2.75 & 0.50 & & 0.34 & \\
\hline Total & 101.27 & 99.98 & 98.88 & 99.93 & 100.42 & 99.22 & 100.54 & 97.94 \\
\hline ASI & 1.24 & 1.14 & 1.45 & 0.95 & 1.10 & 1.39 & 0.97 & 1.02 \\
\hline A/NK & 1.34 & 1.17 & 1.56 & 0.99 & 1.11 & 1.43 & 1.03 & 1.14 \\
\hline
\end{tabular}

ASI is the molar $\mathrm{Al}_{2} \mathrm{O}_{3} /\left(\mathrm{CaO}+\mathrm{Na}_{2} \mathrm{O}+\mathrm{K}_{2} \mathrm{O}\right)$; $\mathrm{A} / \mathrm{NK}$ is the molar $\mathrm{Al}_{2} \mathrm{O}_{3} /\left(\mathrm{Na}_{2} \mathrm{O}+\mathrm{K}_{2} \mathrm{O}\right)$. 
Table 5B

Chemical compositions of representative Cretaceous basaltic rocks in the SCMB

\begin{tabular}{|c|c|c|c|c|c|c|c|c|}
\hline Sample & PY-01 & PY-02 & PY $-09^{\mathrm{a}}$ & JL-01 & LS-01 & ST-01 & SM-02 & YT-05 \\
\hline Age (Ma) & $87.6 \pm 1.0$ & $88.0 \pm 2.7$ & $83.9 \pm 1.5$ & $88.9 \pm 1.7$ & $93.3 \pm 0.5$ & $91.7 \pm 0.5$ & $83.2 \pm 0.5$ & $86.8 \pm 0.7$ \\
\hline Locality & Pingyen & Pingyen & Pingyen & Julipin & Lientoutang & Xuentandi & Shanmeng & Yongtai \\
\hline \multicolumn{9}{|l|}{$\mathrm{Wt} \%$} \\
\hline $\mathrm{SiO}_{2}$ & 50.27 & 43.60 & 50.72 & 48.80 & 50.24 & 48.22 & 48.04 & 50.35 \\
\hline $\mathrm{TiO}_{2}$ & 1.61 & 1.51 & 1.10 & 1.48 & 1.32 & 1.44 & 1.21 & 1.79 \\
\hline $\mathrm{Al}_{2} \mathrm{O}_{3}$ & 18.63 & 16.67 & 17.92 & 17.54 & 18.11 & 17.58 & 18.08 & 17.14 \\
\hline $\mathrm{Fe}_{2} \mathrm{O}_{3}$ & 9.59 & 12.79 & 8.25 & 10.38 & 8.32 & 10.05 & 10.74 & 10.52 \\
\hline $\mathrm{MnO}$ & 0.58 & 0.87 & 0.19 & 0.15 & 0.09 & 0.16 & 0.18 & 0.15 \\
\hline $\mathrm{MgO}$ & 3.45 & 4.79 & 5.29 & 4.30 & 4.63 & 5.80 & 6.36 & 4.59 \\
\hline $\mathrm{CaO}$ & 8.55 & 12.60 & 5.68 & 6.88 & 8.17 & 9.52 & 10.37 & 8.60 \\
\hline $\mathrm{Na}_{2} \mathrm{O}$ & 4.70 & 2.80 & 5.60 & 4.46 & 3.60 & 2.54 & 2.38 & 3.07 \\
\hline $\mathrm{K}_{2} \mathrm{O}$ & 0.94 & 1.33 & 1.65 & 2.31 & 1.86 & 1.25 & 1.50 & 1.53 \\
\hline $\mathrm{P}_{2} \mathrm{O}_{5}$ & 0.46 & 0.43 & 1.40 & 0.40 & 0.41 & 0.42 & 0.50 & 0.49 \\
\hline LOI & 0.88 & 1.99 & 2.68 & 2.73 & 1.10 & 1.89 & 1.63 & 1.64 \\
\hline Total & 99.66 & 99.38 & 99.48 & 99.43 & 97.85 & 98.87 & 100.99 & 99.86 \\
\hline Alk & 5.64 & 4.13 & 7.25 & 6.77 & 5.46 & 3.79 & 3.96 & 4.60 \\
\hline $\mathrm{Mg} \#$ & 45.6 & 46.6 & 59.9 & 49.1 & 56.4 & 57.3 & 58.0 & 50.4 \\
\hline Sample & YT-02-1 & $\mathrm{KS} 02^{\mathrm{a}}$ & $\mathrm{PC} 01^{\mathrm{a}}$ & ZUD02 $2^{\mathrm{a}}$ & $\mathrm{M} 08^{\mathrm{a}}$ & $\mathrm{HS}_{0} 3^{\mathrm{a}}$ & MAS09a & MA- $02^{\mathrm{a}}$ \\
\hline Age (Ma) & $80.7 \pm 1.0$ & $93.3 \pm 0.7$ & $79.9 \pm 0.6$ & $83.0 \pm 1.9$ & $85.3 \pm 2.0$ & $90.4 \pm 2.0$ & $89.9 \pm 2.0$ & $90.4 \pm 2.0$ \\
\hline Locality & Yongtai & Fuzhou & Fuzhou & Zhangzhou & Chinmen & Lieyu & Matsu & Matsu \\
\hline \multicolumn{9}{|l|}{$\mathrm{Wt} \%$} \\
\hline $\mathrm{SiO}_{2}$ & 53.45 & 50.24 & 51.82 & 51.59 & 55.47 & 53.28 & 54.60 & 50.16 \\
\hline $\mathrm{TiO}_{2}$ & 1.53 & 1.99 & 1.51 & 1.00 & 0.97 & 1.07 & 0.81 & 1.81 \\
\hline $\mathrm{Al}_{2} \mathrm{O}_{3}$ & 16.85 & 16.31 & 16.65 & 16.84 & 18.57 & 18.37 & 17.40 & 16.41 \\
\hline $\mathrm{Fe}_{2} \mathrm{O}_{3}$ & 9.30 & 11.45 & 9.42 & 9.01 & 7.60 & 8.62 & 7.67 & 10.55 \\
\hline $\mathrm{MnO}$ & 0.12 & 0.30 & 0.15 & 0.14 & 0.11 & 0.16 & 0.12 & 0.18 \\
\hline $\mathrm{MgO}$ & 3.89 & 4.71 & 4.74 & 6.29 & 3.63 & 3.96 & 4.52 & 6.37 \\
\hline $\mathrm{CaO}$ & 7.26 & 7.71 & 7.34 & 8.53 & 6.70 & 7.02 & 6.89 & 6.73 \\
\hline $\mathrm{Na}_{2} \mathrm{O}$ & 3.24 & 4.43 & 3.01 & 2.79 & 3.69 & 3.41 & 3.54 & 3.24 \\
\hline $\mathrm{K}_{2} \mathrm{O}$ & 2.58 & 1.43 & 2.31 & 1.23 & 1.55 & 1.76 & 1.86 & 1.93 \\
\hline $\mathrm{P}_{2} \mathrm{O}_{5}$ & 0.81 & 0.54 & 0.72 & 0.35 & 0.33 & 0.35 & 0.24 & 0.81 \\
\hline LOI & 0.90 & 0.53 & 2.29 & 2.22 & 1.95 & 2.86 & 2.25 & 1.92 \\
\hline Total & 99.93 & 99.64 & 99.97 & 99.98 & 100.57 & 100.86 & 99.90 & 100.12 \\
\hline Alk & 5.82 & 5.87 & 5.32 & 4.02 & 5.24 & 5.17 & 5.40 & 5.18 \\
\hline $\mathrm{Mg \#}$ & 49.3 & 48.9 & 54.0 & 61.9 & 52.6 & 51.7 & 57.8 & 58.5 \\
\hline
\end{tabular}

$\mathrm{Alk}=\mathrm{wt} \%\left(\mathrm{Na}_{2} \mathrm{O}+\mathrm{K}_{2} \mathrm{O}\right) ; \mathrm{Mg} \#=$ molar $\mathrm{MgO} /(\mathrm{MgO}+0.85 \mathrm{FeO})$ and $\mathrm{FeO}=\mathrm{Fe}_{2} \mathrm{O}_{3} / 1.11$

Note: PY-01 and -02 are rounded inclusions in rhyolites and differ greatly in Alk and Mg\# from PY-09 which is a basaltic dike.

${ }^{a}$ Mafic dikes without prefix.

index) vs. A/NK plots (Fig. 5a). Fractionated I-type granitoids occupy a broad field astride both the metaluminous and peraluminous quadrants with ASI value ranging from 0.88 to 1.16 ; A-type granites have similar range of ASI, but possess lower A/NK values (0.9-1.2) than I-type granites $(1.1-1.5)$ and distribute in a linear trend from the peraluminous, through the metaluminous, to the peralkaline quadrant. Very few of such rocks (3 out of 114 in our collection) are strongly peraluminous (SP, defined as ASI $>1.16$ in this study) along the dashed line in Fig. 5a. Because most of the A-type granites worldwide are metaluminous (although some are peralkaline) and only rare cases are peraluminous to strongly peraluminous (ASI $>1.1$; Frost et al., 2001), A-type granites in the SCMB are somewhat atypical for many of them are peraluminous (Hong et al., 1996; Qiu et al., 2004). Since rhyolitic activities are temporally and spatially in close association with the emplacement of A-type magmas, these rhyolites are examined using the same criteria.

A striking feature is that all the rhyolites in Zhejiang are peraluminous, with bimodal rhyolites possess an obvious SP character (ASI $=1.13-1.54)$ whereas mono-lithologic rhyolites (Pingyen and Taozu) are less peraluminous (ASI $=1.05-1.14)$ (Fig. 5a). Those in Fujian are more complicate: in addition to the SP rocks like Zhejiang, a still large portion of rhyolites is peralkaline to mildly peraluminous (P-MP) overlapping nicely with the A-type granites. Altogether, these rhyolites differ from lower series ones in NW Zhejiang and W Fujian that are mainly metaluminous and fall in the field of I-type granitoids (Lapierre et al., 1997; our unpublished data). On this basis, P-MP rhyolitic rocks can be regarded as eruptive equivalents of combining peralkaline and aluminous A-type granite subgroups of Qiu et al. (2004). Meanwhile, the $101 \mathrm{Ma}$ Julipin rhyolite 

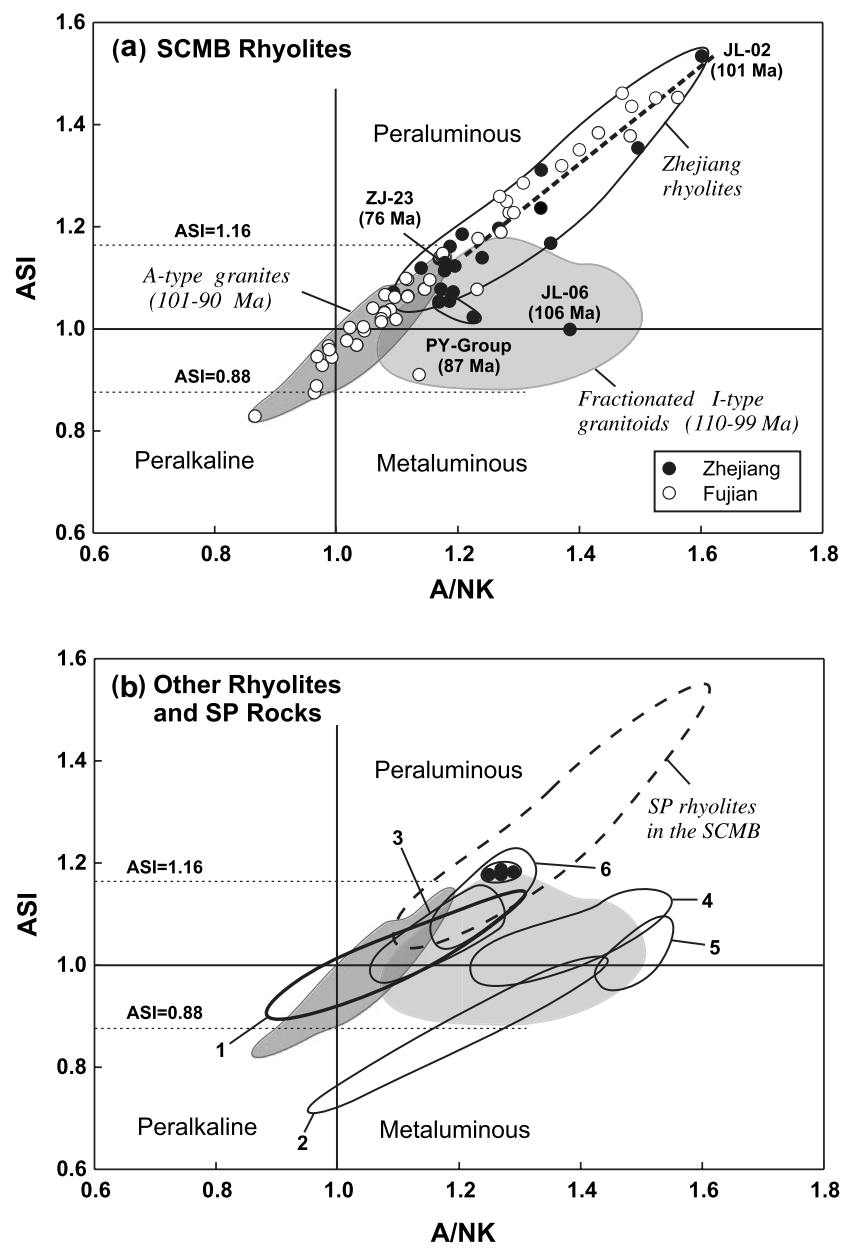

Fig. 5. ASI (alumina saturation index) vs. A/NK (molar $\mathrm{Al}_{2} \mathrm{O}_{3} /$ $\left.\left(\mathrm{Na}_{2} \mathrm{O}+\mathrm{K}_{2} \mathrm{O}\right)\right)$ plots. (a) Rhyolites in the SCBM (101-72 Ma) as compared with the intrusive rocks in the same area. Shaded fields of the fractionated I-type granitoids $(n=62)$ and A-type granites $(n=114)$ are based on data of Martin et al. (1994), Hong et al. (1996), Chen et al. (2000), Qiu et al. (2004) and the unpublished database of igneous rocks of Fujian Province stored in the Fujian Institute of Geology (K.L. Wu, personal communication). Chemical data reported previously for rhyolitic rocks from Xuentandi (Yu et al., 1993), Yongtai-Dehua (Fong et al., 1991), and Jianweishan-Lingtongshan (Wu et al., 1989) are also included. Noted that Fujian rhyolites overlap the distribution field of both the Zhejiang rhyolites and A-type granites in the SCMB that deviates from the I-type granitoid field. Data points circled as PY-Group indicate Pingyen rhyolites. (b) Other rhyolites from silicic large igneous provinces (SLIPs) and typical SP rocks. (1 and 2) northern Basin and Range rhyolites (Scott et al., 1995); (3) Low- $\delta^{18} \mathrm{O}$ Yellowstone rhyolites (Bindeman and Valley, 2001); (4 and 5) the Oruanui rhyolites (Sutton et al., 2000) and Whakamaru ignimbrites (Brown et al., 1998) in the Taupo Volcanic Zone; and (6) representative SP rocks of leucogranites in Himalaya (Searle et al., 1997) in which the black dots are the averaged Manaslu leucogranites of various types (Vidal et al., 1982; Guillot and Le Fort, 1995). Shaded areas are same as in (a). Noted that no rhyolites from major SLIPs show ASI values as high as SP rhyolites in the SCMB.

(JL-02) can be regarded as the end member of the SP rhyolites that situates in the extremity of the linear trend set by all the bimodal rhyolites in the SCMB. When compared with other large rhyolite provinces (Fig. 5b), e.g., the northern Basin and Range, W United States (Scott et al., 1995), the Yellowstone Plateau, Idaho (Bindeman and
Valley, 2001), and the Taupo Volcanic Zone (Brown et al., 1998; Sutton et al., 2000), no any rhyolites from these provinces possess such high peraluminosity comparable with the SP rhyolites in the SCMB. Even the well-known SP rocks, such as Himalaya leucogranites (including Manaslu) (Vidal et al., 1982; Searle et al., 1997; Guillot and Le Fort, 1995), the peraluminosity is far less than these SP rhyolites. Thus, SP rhyolites in the SCMB are chemically unique.

Basically, the SP character is a consequence of relatively high $\mathrm{Al}_{2} \mathrm{O}_{3}$ and low $\mathrm{CaO}$ contents in these rhyolitic rocks. Experimentally, Patiño Douce (1999) concluded that there are only two groups of igneous rock that can be of SP characteristics: leucogranites and "S-type" granites (and their volcanic equivalents), distinguished by lower $\mathrm{CaO} / \mathrm{Al}_{2} \mathrm{O}_{3}$ ratios $(<0.1)$ in the former and higher ratios $(0.3-0.1)$ in the latter. Moreover, SP rocks (e.g., post-collisional Manaslu leucogranites) have $\mathrm{CaO} / \mathrm{Na}_{2} \mathrm{O}$ ratios varying from 1 to 0.1 (Sylvester, 1998). Most SP rhyolites in the SCMB have even lower $\mathrm{CaO} / \mathrm{Al}_{2} \mathrm{O}_{3}(0.06-0.01)$ and $\mathrm{CaO} / \mathrm{Na}_{2} \mathrm{O}$ ratios (0.2-0.03) ascribing to the low $\mathrm{CaO}$ contents $(0.9$ $0.2 \mathrm{wt} \%$ in Zhejiang and $0.7-0.1 \mathrm{wt} \%$ in Fujian samples). Therefore, these SP rhyolites may represent rare cases of low-Ca volcanic rocks in the continental margin complexes.

Basalts are in close association with these P-MP and SP rhyolites in space and time as well. There are no discernible differences of major element compositions between basalts and mafic dikes. $\mathrm{Mg}$ numbers, ranging from 46 to 60 for basalts and 49 to 62 for mafic dikes (Table 5B), suggest derivatives after certain degree of magma differentiation. Their high-Al character $\left(\mathrm{Al}_{2} \mathrm{O}_{3}>16.9 \mathrm{wt} \%\right)$ is typical of basaltic rocks in the subduction-influenced orogenic belt (Pitcher, 1997). Formation of rhyolites in the SLIPs usually requires extraordinary heat sources. For example, rhyolites of the central Snake River Plain were generated by shallow melting of Idaho batholith rocks under the influence of the Yellowstone hotspot (Boroughs et al., 2005). In the SCMB, contemporaneous basaltic rocks are the clues for extra heat supply.

\section{Discussion}

Our age and chemical data support the volcanic evolution scheme in SE China as proposed by Tao et al. (2000): $135-110 \mathrm{Ma}$ for the lower volcanic series; $<100 \mathrm{Ma}$ for the upper volcanic series; and 110-100 Ma for a transitional period between these two series. Accordingly, shallow-leveled, calc-alkaline I-type granitoids widespread in the SCMB were largely emplaced at the transitional period. One bimodal suite in Julipin (JL-05 and JL-06) also erupted at this time. Because the composition of rhyolite sample JL-06 is deviated greatly from the main rhyolite trend and falls in the field of I-type granitoids (Fig. 5a), it is considered as their silicic volcanic equivalent and is beyond the scope of the present focus. Then, rhyolite sample JL-02 of Julipin (101 Ma) is the representative for 
the earliest phase of upper series based on its unique SP character. Eruptions of bimodal suites had been accompanied by intrusions of A-type granite in the early stage, but no such intrusions occurred in the epilogue of the LY orogenic cycle $(<90 \mathrm{Ma})$. SP rhyolites in the SCMB, however, display chemical distinctions from those of vigorous silicic magmatism developed in an active convergent margin undergoing extension (Bryan et al., 2002). In addition, the age span for basaltic rocks and mafic dikes provides an evidence to indicate that there had been a continuous supply of basic magmas during the time when activities of A-type granitic and rhyolitic magmas prevailed.

Some important rocks that can reflect earlier magmatism of the LY orogenic cycle in SE China are metamorphic complexes in the CNMB. The time (130-110 Ma) and depths $(18-24 \mathrm{~km})$ of emplacement of their granitic gneisses prior to shear deformation define the plutonism due to compressional forces (Chen et al., 2004). Combining the juxtaposed volcanism (lower series) in the SCMB, the overall magmatism in this stage would be most appropriate to delineate the syn-orogenic thermal activities. Like many orogenic belts (e.g., Pitcher, 1997), the post-orogenic SE China coastal orogen is marked by shallow intruded I-type granitoids, and the following A-type granites representing the more extensive extension in the post-collisional setting ( $\mathrm{Li}, 2000)$. Igneous rocks with the SP character worldwide are mainly intrusive and formed by post-collisional extension in various orogens (Sylvester, 1998). SP rocks in the SCMB are extrusive, present in the extension environment as well, and especially those in Fujian are in close association with P-MP rhyolites. Whether P-MP rhyolites and Atype granites have a comagmatic relationship and what are major sources for these SP rhyolites within the same evolved tectonic setting are elucidated in the following.

Genesis of P-MP rhyolites are at first linked to magma generation of peralkaline and aluminous A-type granites for the similar behavior on major elements. There are two main considerations: crystal fractionation of a common basic magma versus partial melting of contrasting sources for these two subgroups. Martin et al. (1994) suggested that peralkaline A-type granites in Kuiqi were formed by mixing between mantle-derived melts and calcalkaline crust and then followed by a large degree of crystal separation. Qiu et al. (2004), based mainly on the Sr and $\mathrm{Nd}$ isotope data, further suggested that A-type granites in SE China have involved remelting of ancient basement rock (up to $60 \%$ in Zhejiang) in addition to the mantle sources, and different differentiation trends $( \pm \mathrm{Cl}$ and $\mathrm{F})$ result in the peralkaline and aluminous characters. Silicic rocks evolved from basalts through crystal fractionation indeed are often peralkaline in nature (Frost et al., 2001). However, one fundamental difficulty to apply the crystal fractionation model in the SCMB is the volume problem. With the volcanic rocks overwhelmed by rhyolites and lack of accompanied intermediate rocks in many volcanic basins, application of this petrogenetic model on a regional scale seems less convincing.
Common existence of A-type granites and coeval mafic dikes in the SCMB, Fujian in particular, reflects extra heat supply in the crust that can cause remelting of residues left after the generation of precedent I-type magmas (Chen et al., 2000). We basically adopt the idea of continuous crust melting to explain the genesis of P-MP and SP rhyolites and the accompanying A-type subgroups, although the process through fractionation of basaltic magma can not be totally ruled out. So far, experimental works dealing with the melting petrogenesis of various kinds of A-type granites have reached the following merits (Martin, 2006). (1) Partial melting of the felsic "residue source" (Clemens et al., 1986) or melts produced by dehydration melting of mica plus quartz (Patiño Douce, 1999) can well satisfy the aspect of the major element composition with the SP character. (2) Partial melting of tonalite and granodiorite at low pressure condition (4 kbar) can fit many characteristics of the metaluminous A-type granite (Patiño Douce, 1997). (3) As for peralkaline composition, the formation of comenditic magma through the fractionation from a pantelleritic melt (Scaillet and Macdonald, 2003) is a rare case, hence, a crust source modified by mantlederived, fenitization-type metasomatism is suggested. With reference to these works and isotopic data available (particularly Nd isotope) for A-type rocks in the SCMB, their petrogenesis is briefly narrated.

In Fujian, because all the A-type rocks (granites and rhyolites) have $\mathrm{Nd}$ isotopic compositions similar to the trondhjemite-tonalite-granodiorite assemblage of the CNMB metamorphic core complexes (Martin et al., 1994; Chen et al., 2000, 2004, 2007; Qiu et al., 2004), P-MP rocks are interpreted as derived from melting of these complexes and SP rhyolites from melting of their associated low-Ca felsic (quartzofeldspathic) granites and metasedimentary rocks (Lin, 2001). On this basis, peralkaline A-type granites, less in volume than the aluminous ones, are due to higher melting temperature of more basic and sodic source rocks such as trondhjemite-a leuco-quartz diorite with oligoclase as the sole feldspar. On the other hand, A-type granites (Qiu et al., 2004) and rhyolites (Chen et al., 2007) in Zhejiang are thought to have originated from different sources because of more enriched $\mathrm{Nd}$ isotopic compositions. Ascribing to the dominance of peralkaline compositions (Qiu et al., 2004), A-type granites here are more likely derived from partial melting of fenitizationtype metasomatized pre-LY intrusives, e.g., the vast EY granitoids in S China (Hsieh et al., 2007). Rhyolites are further considered for more MP and SP members, with the former (mainly mono-lithologic rhyolites) derived from fractionation of basalt magmas (e.g., the PY-group of rocks that seemingly vary along the I-type trend in Fig. 5a) and the latter from more quartzofeldspathic sources that relatively require lower melting temperatures. Besides, near surface contamination to these rhyolites can explain the existence of a cluster of $\sim 89$ Ma zircons in sample ZJ-23 and minor involvement of metapelite or the protolith with sedimentary origin to SP rhyolites is inevitable 
to accommodate $\sim 1750-220 \mathrm{Ma}$ inherited zircons in sample JL-02.

Accordingly, magmas generated by progressive melting of quartzofeldspathic granite ( \pm metapelite), tonalite and granodiorite, and trondhjemite sources took place in one thermal regime can account for the decreasing aluminosity of the studied rhyolites (Fig. 5a). This is supported by our results that rhyolites with higher ASI values (e.g., samples JL-02 in Zhejiang and 20FJ-16 in Fujian) had erupted earlier (Table 5A), a sign to reflect that melting probably began at lower temperature sources. Also the dominance of P-MP (A-type) magmas in Zhejiang at 94-91 Ma (Chen et al., 2000; Qiu et al., 2004) and in Fujian at 85-81 Ma (this study) indicates a time lag for the temperature maximum of magma source regions between northern and southern parts of the SCMB. We suggest that, as juxtaposed to the $\mathrm{CNMB}$, there has been a pronounced tendency for the south SCMB to be equally emplaced by this metamorphic complex assemblage at the LY syn-orogenic stage. As for the north SCMB, intrusive equivalents for the lower volcanic series are potential candidates for low pressure crust melting. Presence of a cluster of $\sim 130 \mathrm{Ma}$ zircons in sample JL-02 (Fig. 4a) provides the evidence of relicts from young sources rather than a major component of ancient basement rocks (Qiu et al., 2004).

The heat source for crust melting can be manifested by the existence of a high velocity $(>7.2 \mathrm{~km} / \mathrm{s})$ layer $\sim 7 \mathrm{~km}$ thick beneath the coastal Fujian (Xu et al., 1996), a clue to link with underplating of mafic magmas. There are two different views concerning thermal effects of mafic underplating in relation to the Yanshanian magmatism. Zhou and Li (2000) suggested that basaltic melts, induced by dehydration of the subducted paleo-Pacific plate since the late Jurassic, ascended to the base of the lower crust in SE China. Whether such melts provided substantial heat to cause melting of the lower to middle crust over a period of $\sim 100$ Myr to account for the Yanshanian magmatism needs to be considered more thoroughly. One difficulty is that their low-angle subduction model would result in a thermal barrier made by the cold slab in the mantle wedge. Alternatively, delamination of lithosphere is suggested as the major controlling factor under which the lithospheric root is replaced by hotter upwelling mantle (Chen et al., 2000).

Under the condition of delamination and mafic underplating, a density layer can be formed by I-type magmas in the middle crust to prevent underplated melts from leaking out in great amounts (Handy and Streit, 1999). This explains the rarity of basic rocks in the SCMB. With the generation of silicic melts residing in a molten state at high levels of the crust, shallow magma chambers were formed. Episodic invasions of basaltic melt into these magma chambers (e.g., the Pingyen case) may be the reason for alternating eruptions of silicic and basic magmas. Time sequence of P-MP relative to SP rocks probably reflects different $\mathrm{P} / \mathrm{T}$ conditions of the thermal regime in Zhejiang and Fujian under a continuous continental stretching. How the lower pressure melting conditions can merge into this extensional framework is further tested with numerical modeling.

\section{Numerical simulation}

Generation of A-type magmas requires higher temperatures than I-type magmas (Clemens and Vielzeuf, 1987). Tectonically, delamination occurs before the shallow I-type magmatic stage, with a heat pulse resulting from the underplating of basaltic magma (Huppert and Sparks, 1988). Two cases are dealt with by using a thermal conduction model on numerical simulation. Case 1 aims to test the effect of crust temperature due to continuous mafic underplating throughout the I- and A-type magma generating stages under plate subduction (Zhou and Li, 2000). Case 2 represents a lithosphere extension with mafic underplating restricted to the A-type magmatic stage (Chen et al., 2000). All simulations are based on a two-layered doublecrustal lithosphere (Spear, 1993; Zito, 2005), and the physical parameters required for these simulations are listed in Table 6.

Variables on the underplating of mafic magma include the total thickness, the time span, emplacement depths, magma influx rates, and temperature. The thickness of underplating melts chosen is $10 \mathrm{~km}$ (Sinigoi et al., 1995), and underplating durations are designed as $115-80 \mathrm{Ma}$ for case 1 and $95-80 \mathrm{Ma}$ for case 2, respectively. This gives magma influx rates to be 0.286 and $0.666 \mathrm{~mm} / \mathrm{yr}$. On the basis of the density-controlled model (Sinigoi et al., 1995), the initial intrusion is emplaced at $30 \mathrm{~km}$, and the subsequent magma is assumed to penetrate the denser gabbroic layer and be trapped in the lighter partially molten zone of the lower crust (Handy and Streit, 1999). Temperatures of the simulated mafic underplate are $1373 \mathrm{~K}$ and $1473 \mathrm{~K}$ (Thompson, 1999).

The thickness of lithosphere varies as a consequence of combining effects of mafic underplating, lithosphere extension and crust exhumation. Since the crust of the SCMB

Table 6

Thermal parameters and layer thickness of the 2-layer lithosphere model ${ }^{\mathrm{a}}$

\begin{tabular}{|c|c|c|c|c|c|}
\hline Layer & $\begin{array}{l}\text { Depth } \\
(\mathrm{km})\end{array}$ & $\begin{array}{l}\text { Density } \\
\left(\mathrm{kg} \mathrm{m}^{-3}\right)\end{array}$ & $\begin{array}{l}\text { Heat capacity } \\
\left(\mathrm{J} \mathrm{kg}^{-1} \mathrm{~K}^{-1}\right)\end{array}$ & $\begin{array}{l}\text { Thermal conductivity } \\
\left(\mathrm{W} \mathrm{m} \mathrm{m}^{-1} \mathrm{~K}^{-1}\right)\end{array}$ & $\begin{array}{l}\text { Heat production } \\
\left(\mu \mathrm{W} \mathrm{m} \mathrm{m}^{-3}\right)\end{array}$ \\
\hline Crust & $0-60$ & 2750 & 1000 & 2.25 & 0.75 \\
\hline Lithospheric mantle & $60-100$ & 3300 & 1250 & 1.95 & 0.0 \\
\hline Underplated mafic magma & & 3300 & 1250 & 2.5 & 0.0 \\
\hline
\end{tabular}

a After Spear (1993). 
has been unroofed about 3-4 km during 110-99 Ma (Chen et al., 2000), we assume $5 \mathrm{~km}$ in total unroofing for the entire mafic underplating stage. Thus, exhumation rates are $0.143 \mathrm{~mm} / \mathrm{yr}$ and $0.333 \mathrm{~mm} / \mathrm{yr}$, respectively, in these two cases to counteract the effect of magma underplating. For case 2, various extension rates are simulated by applying different lithosphere thickness at the time of the initiation of mafic underplating, and a constant thickness for the crust unroofing since then.

The present modeling needs to solve the following timedependent 1-D heat transfer equation (Spear, 1993):

$\frac{\partial T}{\partial t}=\frac{K}{\rho c} \nabla^{2} T+\frac{A}{\rho c}$

where $T$ is the temperature in $\mathrm{K}, t$ the time in seconds, $K$ the thermal conductivity in $\mathrm{W} \mathrm{m}^{-1} \mathrm{~K}^{-1}, A$ the internal heat production in $\mathrm{W} \mathrm{m}^{-3}, \rho$ the density of the medium in $\mathrm{kg} \mathrm{m}^{-3}$ and $c$ the specific heat in $\mathrm{J} \mathrm{kg}^{-1} \mathrm{~K}^{-1}$. The radioactive decay in the crust is considered the only source of internal heat production for a long simulation time (Spear, 1993). The model is solved by the finite element method and meshed by 1-D linear elements. Sizes of these elements are regular $100 \mathrm{~m}$ in length, temperatures for the surface and the lithosphere-asthenosphere interface are set at $283 \mathrm{~K}$ and $1573 \mathrm{~K}$ (Huppert and Sparks, 1988; Zito, 2005), and the duration of the transient simulation is $45 \mathrm{Myr}$ (115-70 Ma). The depth-temperature (P-T) relationships varying with time are shown in Fig. 6, in which case 2 is based on a lithosphere thickness of $70 \mathrm{~km}$ at $95 \mathrm{Ma}$, or an extension rate of $1.75 \mathrm{~mm} / \mathrm{yr}$.

Simulated results under $1473 \mathrm{~K}$ indicate that the geothermal state is enhanced only in the early stage (110 $100 \mathrm{Ma}$ ) of mafic underplating for case 1 (Fig. 6a). Since the magma underplating increases the thickness of lithosphere and gradually dominates the geothermal system, the crust geotherm then drops below the initial state (curve of $115 \mathrm{Ma}$ ) by $100 \mathrm{Ma}$. This demonstrates that melting would have occurred at great depths $(>35 \mathrm{~km})$, and the mafic underplating alone is not able to maintain high temperatures for LY magmatism at all stages. Therefore, the effect of continuous recharge of mafic magma under the process of a plate subduction is mainly to thicken the crust.

On the other hand, results for case 2 reveal that thinning of the lithosphere thickness to $70 \mathrm{~km}$ from 115 to $95 \mathrm{Ma}$
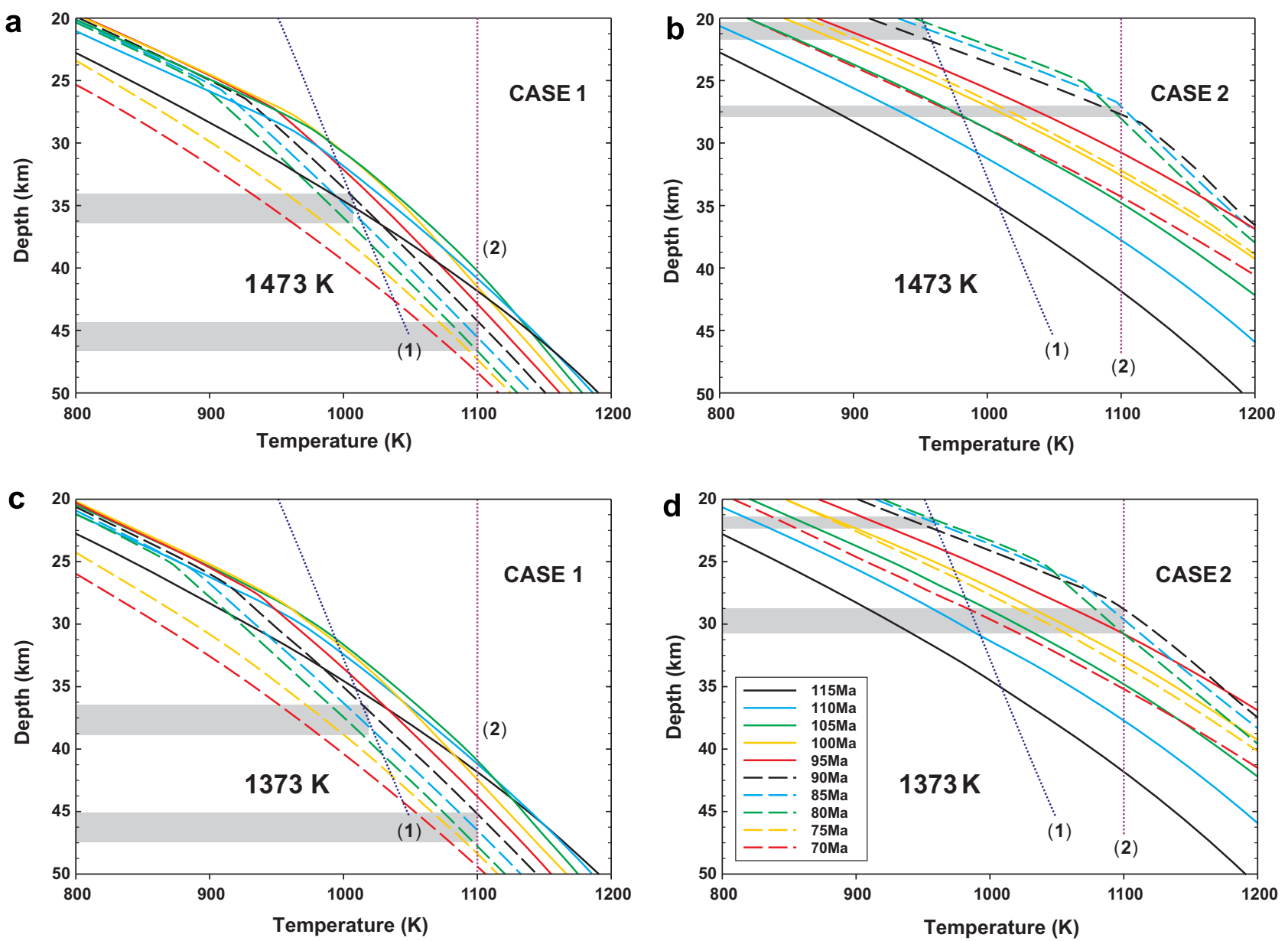

Fig. 6. Time-dependent depth-temperature (P-T) evolution curves in the SCMB under the continuous underplating model (a and c) and the lithosphere extension model ( $\mathrm{b}$ and d) for two mafic underplating temperatures: $1473 \mathrm{~K}$ and $1373 \mathrm{~K}$. Lines labeled by (1) and (2) denote the biotite decomposition curve and the solidus of the A-type rock (Clemens and Vielzeuf, 1987) and represent the minimum temperature for generating I- and A-type magmas, respectively. Depths that bracket the intersection of P-T curves for 90-80 Ma and lines (1) and (2) are shaded. 
can cause crust melting to produce I-type magmas after $110 \mathrm{Ma}$, and the geothermal state thus developed is close to the condition suitable for generating A-type magmas at $95 \mathrm{Ma}$ (Fig. 6b). Adding the mafic underplating from $95 \mathrm{Ma}$, all the curves of $95-80 \mathrm{Ma}$ intersect the solidus of A-type magma above $28 \mathrm{~km}$ or the dehydration melting curve of biotite above $21 \mathrm{~km}$, and the maximum geothermal gradient occurs at $90 \mathrm{Ma}$. This conforms very well the timing that majority of A-type rocks in Fujian were formed. Because heat conduction from succeeding basaltic melts in an area would become waning through time, generation of A-type magmas is episodic and concentrated in areas of high extension. Termination of bimodal volcanism in any volcanic basin is therefore a sign that underplating was no longer taking place.

Simulated results under $1373 \mathrm{~K}$ for case 1 are similar to those under $1473 \mathrm{~K}$, but about $3 \mathrm{~km}$ deeper for magma generation (Fig. 6c). The results for case 2 are very much alike case 1, i.e. depths of magma generation becomes deeper (Fig. 6d). However, giving a greater extension corresponding to the lithosphere thickness about $65 \mathrm{~km}$ (or $65 \%$ of the original thickness) and a lower underplating temperature (1373 K), A-type magmas can be produced at the same depth as deduced from $1473 \mathrm{~K}$. It thus can be summarized that crust thinning is the most important factor to maintain a high geothermal state in the crust. Because the core complex emplaced at $18-24 \mathrm{~km}$ and the unroofed crust was 3-4 km during 110-100 Ma, the depth of sources barely fulfills the low pressure maximum (15 km, Patiño Douce, 1997) for the formation of SCMB rhyolites through melting of the core complex at $\sim 100 \mathrm{Ma}$. This probably explains the early generation of sole SP magmas in Zhejiang. As the exhumation rate had kept same as the given value of $0.333 \mathrm{~mm} / \mathrm{yr}$ due to rebound after delamination and lithospheric extension became more extensive in the SCMB, P-MP magmas largely formed at the climax of the thermal state (90-80 Ma, Fig. $6 b$ and d).

\section{Conclusions}

The most striking feature drawn from age and major element data for the Late Cretaceous silicic volcanic rocks in the SCMB is the presence of SP rhyolites in the continental margin. They are spatially in close association with and temporally somewhat predating P-MP rhyolites or A-type granites in adjacent areas. Compositional similarity between P-MP rhyolites and A-type granites defines these rhyolites A-type as well. SP rhyolites may bear same genetic processes as A-type rocks for they sit in a linear extension from these A-type rocks and differ from other SLIPs in the ASI-A/NK variation diagram. On the basis of experimental works, progressive melting of quartzofeldspathic granitic ( \pm metapelitic) sources and the associated trondhjemite, tonalite and granodiorite (the metamorphic core complex) would be the most plausible petrogenetic model for SP and P-MP rocks in Fujian. Due to lack of
P-MP rhyolites in Zhejiang, melting from different sources, such as the pre-LY quartzofeldspathic granites or the intrusive equivalents of the lower volcanic series, is postulated for SP rhyolites here although the process of fractionation from basic magmas can not be totally ruled out. Numerical modeling further demonstrates that Late Cretaceous SP rhyolites in the SCMB reflect regional-scale crustal melting processes in response to continental extension and high thermal ( \pm mass) input from underlying hot mantle-derived materials. Among major factors that can govern the generation of such silicic magmas in complex active convergent margins, e.g., the hydrous condition of source regions, temperature of underplating mafic magmas, and degree of lithospheric extension (exhumation rate dependent), the last factor is suggested to be the most important. In areas undergoing continental stretching and crust attenuation, mafic magmas can reach higher levels through vigorous dike injection and cause melting of juvenile upper crusts by mafic underplating. Therefore, this particular tectonic environment of the SCMB allows shallow crust origin of SP and P-MP rhyolites.

\section{Acknowledgements}

The authors are indebted to K.L. Wu (Fuzhou), K.Y. Tao (Nanjing) and Dr. W. Lin (Taipei) for field assistance and discussions at various stages. Drs. C.H. Lo and S. Tsao (Taipei) and S. Gao (Xian) are thanked for their helps in ${ }^{40} \mathrm{Ar} /{ }^{39} \mathrm{Ar}$ and $\mathrm{K} / \mathrm{Ar}$ whole-rock and $\mathrm{U}-\mathrm{Pb}$ zircon age dating, respectively, and Dr. Y. Iizuka (Taipei), for zircon CL images. We are benefited greatly from Prof. J. Chen (Hefei) and one anonymous reviewer for their corrections and constructive comments. This paper is made possible by research grants from the National Science Council, ROC (NSC86-2116-M002-003/Chen, and NSC87(88)2116-M002-008(002)/Lee).

\section{References}

Andersen, T., 2002. Correction of common lead in $\mathrm{U}-\mathrm{Pb}$ analyses that do not report ${ }^{204} \mathrm{~Pb}$. Chemical Geology 192, 59-79.

BGMRFJ (Bureau of Geology and Mineral Resources of Fujian Province), 1985. Regional geology of Fujian Province. Geological Publishing House, Beijing, 617pp. (in Chinese with English abstract).

BGMRZJ (Bureau of Geology and Mineral Resources of Zhejiang Province), 1989. Regional geology of Zhejiang Province. Geological Publishing House, Beijing, 688pp. (in Chinese with English abstract).

Bindeman, I.N., Valley, J.W., 2001. Low- $\delta^{18}$ O rhyolites from Yellowstone: Magmatic evolution based on analyses of zircons and individual phenocrysts. Journal of Petrology 42, 1491-1517.

Bingen, B., Boven, A., Punzalan, L., Wijbrans, J.R., Demaiffe, D., 1998. Hornblende ${ }^{40} \mathrm{Ar} /{ }^{39} \mathrm{Ar}$ geochronology across terrane boundaries in the Sveconorwegian Province of S Norway. Precambrian Research 90, 159-185.

Boroughs, C., Wolff, J., Bonnichsen, B., Godchaus, M., Larson, P., 2005. Large-volume low- $\delta^{18} \mathrm{O}$ rhyolites of the central Snake River Plain, Idaho, USA. Geology 33, 821-824.

Brown, S.J.A., Wilson, C.J.N., Cole, J.W., Wooden, J., 1998. The Whakamaru group ignimbrites, Taupo Volcanic Zone, New Zealand: 
evidence for reverse tapping of a zoned silicic magmatic system. Journal of Volcanology and Geothermal Research 84, 1-37.

Bryan, S.E., Allen, C.M., Holcombe, R.J., Fielding, C.R., 2004. U-Pb zircon geochronology of Late Devonian to Early Carboniferous extension-related silicic volcanism in the northern New England Fold Belt. Australian Journal of Earth Sciences 51, 645-664.

Bryan, S.E., Riley, R.R., Jerram, D.A., Stephens, C.J., Leat, P.T., 2002. Silicic volcanism: an undervalued component of large igneous provinces and volcanic rifted margins. In: Menzies, M.A., Klemperer, S.L., Ebinger, C.J., Baker, J. (Eds.), Volcanic Rifted Margins. Boulder, Colorado, Geological Society of America Special Paper 362, pp. $99-120$.

Charvet, J., Lapierre, H., Yu, Y.W., 1994. Geodynamic significance of the Mesozoic volcanism of southeastern China. Journal of Southeast Asian Earth Science 9, 387-396.

Chen, C.-H., Lee, C.Y., Lu, H.Y., Hsieh, P.S, 2007. Generation of Late Cretaceous strongly peraluminous and peralkaline to mildly peraluminous silicic rocks in SE China coastal areas: age, geochemical, $\mathrm{Sr}$ and $\mathrm{Nd}$ isotopic and numerical constraints (Abstract). XXIV IUGG General Assembly, Perugia, Italy, VS016.

Chen, C.-H., Lin, W., Lee, C.Y., Tien, J.L., Lu, H.Y., Lai, Y.H., 2000. Cretaceous fractionated I-type granitoids and metaluminous A-type granites in SE China: the Late Yanshanian post-orogenic magmatism. Transaction Royal Society of Edinburgh: Earth Science 91, 195-205.

Chen, C.-H., Lin, W., Lan, C.Y., Lee, C.Y., 2004. Geochemical and Sr, $\mathrm{Nd}$ isotopic characteristics and tectonic implications for three stages of igneous rock in the Late Yanshanian (Cretaceous) orogeny, SE China. Transaction Royal Society of Edinburgh: Earth Science 95, 237-248.

Chen, C.-H., Lu, H.Y., Lin, W., Lee, C.Y., 2006. Thermal event records in SE China coastal areas: Constraints from monazite ages of beach sands from two sides of the Taiwan Strait. Chemical Geology 231, 118-134.

Chen, J., Jahn, B.M., 1998. Crustal evolution of southeastern China: $\mathrm{Sr}$ and $\mathrm{Nd}$ isotopic evidence. Tectonophysics 284, 101-133.

Clemens, J.D., Holloway, J.R., White, A.J.R., 1986. Origin of an A-type granite: Experimental constraints. American Mineralogist 71, 317-324.

Clemens, J.D., Vielzeuf, D., 1987. Constraints on melting and magma production in the crust. Earth and Planetary Science Letters 86, $287-306$.

Fong, Z., Huang, S., Li, J., Xe, M., Wang, G., Hei, W., Qi, R., Zhiou, Y., $\mathrm{Wu}, \mathrm{Z}$., 1991. Mesozoic volcanology and mineralization related to volcanics in Yongtai-Dehua district, Fujian Province. Bulletin of Nanjing Institute of Geology and Mineral Resources Supplement 9, 1-100 (in Chinese with English Abstract).

Frost, B.R., Barnes, C.G., Collins, W.J., Arculus, R.J., Ellis, D.J., Frost, C.D., 2001. A geochemical classification for granitic rocks. Journal of Petrology 42, 2033-2048.

Fuhrmann, U., Lippolt, H.J., Hess, J.C., 1987. Examination of some proposed $\mathrm{K}-\mathrm{Ar}$ standards: $\mathrm{Ar}^{40} / \mathrm{Ar}^{39}$ analysis and conventional data. Chemical Geology 66, 41-51.

Guillot, S., Le Fort, P., 1995. Geochemical constraints on the bimodal High Himalayan leucogranites. Lithos 35, 221-234.

Handy, M.R., Streit, J.E., 1999. Mechanics and mechanisms of magmatic underplating: Inferences from mafic veins in deep crustal mylonite. Earth and Planetary Science Letters 165, 271-286.

Hong, D.W., Wang, S.G., Han, B.F., Jin, M.Y., 1996. Post-orogenic alkaline granites from China and comparisons with anorogenic alkaline granites elsewhere. Journal of Southeast Asian Earth Science $13,13-27$.

Hsieh, P.S., Chen, C.-H., Yang, H.J., Lee, C.Y., 2007. The applicability of using apatite geochemistry for differentiating Mesozoic I- and S-type and intermediary granites in S China (Abstract). XXIV IUGG General Assembly, Perugia, Italy, VS016.

Huppert, H.E., Sparks, R.S.J., 1988. The generation granitic magmas by intrusion of basalt into continental crust. Journal of Petrology 29, $599-624$.

Lapierre, H., Jahn, B.M., Charvet, J., Yu, Y.W., 1997. Mesozoic magmatism in Zhejiang province and its relation with the tectonic activities in SE China. Tectonophysics 274, 321-338.
Li, K.Y., Shen, J.L., Wang, X.P., 1989. Isotopic geochronology of Mesozoic volcanics in the Jiangsu, Fujian and Jiangxi provinces. Bulletin of Nanjing Institute of Geology and Mineral Resources Supplement 5, 87-136 (in Chinese with English abstract).

Li, K.Y., Wang, X.P., Shen, J.L., 1988. Age assignment of the Jiande Group, Zhejiang province. Geology Review 34, 485-495 (in Chinese with English abstract).

Li, X.H., 2000. Cretaceous magmatism and lithospheric extension in southeast China. Journal of Asian Earth Science 18, 293-305.

Lin, W., 2001. Late Yanshanian intrusive magmatism in the coastal region of South China and its tectonic implication. Unpublished $\mathrm{PhD}$ thesis, National Taiwan University, Taipei, (in Chinese with English Abstract).

Lo, C.H., Lee, C.Y., 1994. ${ }^{40} \mathrm{Ar} /{ }^{39} \mathrm{Ar}$ method of $\mathrm{K}-\mathrm{Ar}$ age determination of geological samples using Tsing-Hua Open-pool Reactor (THOR). Journal of the Geological Society of China 37, $143-164$.

Ludwig, K.R., 2001. ISOPLOT 2.49: A Geochronological Toolkit for Microsoft Excel. Berkeley Geochronology Centre Special Publication, vol. 1a. University of California at Berkeley, pp. 1-58.

Martin, H., Bonin, B., Capdevila, R., Jahn, B.M., Lameyre, J., Wang, Y., 1994. The Kuiqi peralkaline granitic complex (SE China): Petrology and geochemistry. Journal of Petrology 35, 983-1015.

Martin, R.F., 2006. A-type granites of crustal origin ultimately result from open-system fenitization-type reactions in an extensional environment. Lithos 91, 125-136.

Nairn, A., Shane, P.R., Cole, J.W., Leonard, G.J., Self, S., Pearson, N., 2006. Rhyolite magma processes of the $\sim$ AD 1315 Kaharoa eruption episode, Tarawera volcano, New Zealand. Journal of Volcanology and Geothermal Research 131, 265-294.

NIGMR (Nanjing Institute of Geology and Mineral Resources), 1987. Late Mesozoic volcanism of Zhejiang, Fujian, Jiangxi and Guangdong. Geological Memoir Series 1, vol. 12, Geological Publishing House, Beijing (in Chinese with English abstract).

Patiño Douce, A.E., 1997. Generation of metaluminous A-type granites by low-pressure melting of calc-alkaline granitoids. Geology 25, 743-746.

Patiño Douce, A.E., 1999. What do experiments tell us about the relative contributions of crust and mantle to the origin of granitic magmas?. In: Castro A., Fernandez, C., Vigneresse, J.L. (Eds.), Understanding Granites: Integrating New and Classical Techniques, Geological Society Special Publications, vol. 168. Geological Society of London, pp. $55-75$.

Pitcher, W.S., 1997. The Nature and Origin of Granite, second ed. Chapman and Hall, London.

Qiu, J.S., Wang, D.Z., McInnes, B.I.A., Jiang, S.Y., Wang, R.C., Kanisawa, S., 2004. Two subgroups of A-type granites in the coastal area of Zhejiang and Fujian Provinces, SE China: age and geochemical constraints on their petrogenesis. Transaction Royal Society of Edinburgh: Earth Science 95, 227-236.

Roddick, J.C., 1987. Generalized numerical error analysis with applications to geochronology and thermodynamics. Geochimica et Cosmochimica Acta 51, 2129-2135.

Scaillet, B., Macdonald, R., 2003. Experimental constraints on the relationships between peralkaline rhyolites of the Kenya Rift Valley. Journal of Petrology 41, 1207-1239.

Scott, R.B., Unruh, D.M., Snee, L.W., Harding, A.E., Nealey, L.D., Blank, H.R., Budahn, J.R., Mehnert, H.H., 1995. Relation of peralkaline magmatism to heterogeneous extension during the middle Miocene, southeastern Nevada. Journal of Geophysical Research 100, 10381-10401.

Searle, M.D., Parris, R.R., Hodges, K.V., Hurford, A., Ayres, M.W., Whitehouse, M.J., 1997. Shisha Dangma leucogranite, South Tibetan Himalaya. Journal of Geology 105, 295-317.

Sinigoi, S., Quick, J.E., Mayer, A., Demarchi, G., 1995. Densitycontrolled assimilation of underplated crust, Ivrea-Verbano zone, Italy. Earth and Planetary Science Letters 129, 183-191.

Spear, F.S., 1993. Heat flow and metamorphism. In: Spear, F.S. (Ed.), Metamorphic Phase Equilibria and Pressure-Temperature-Time Paths. Mineralogical Society of America, Washington, DC, pp. 25-72. 
Steiger, R.H., Jager, E., 1977. Subcommission on geochronology: convention on the use of decay constants in geo- and cosmochronology. Earth and Planetary Science Letters 36, 359-362.

Sutton, A.N., Blake, S., Wilson, C.J.N., Charlier, B.L.A., 2000. Late Quaternary evolution of a hyperactive rhyolite magmatic system: Taupo volcanic centre, New Zealand. Journal of the Geology Society London 157, 537-552.

Sylvester, P.J., 1998. Post-collisional strongly peraluminous granites. Lithos 45, 29-44.

Tao, K., Xing, G., Yang, Z., Mao, J., Zhou, N., Xu, N., 2000. Discussions on the problem and timing of Mesozoic volcanic rocks in Zhejiang. Geological Review 16, 14-20 (in Chinese).

Thompson, A.B., 1999. Some time-space relationships for crustal melting and granitic intrusion at various depths. In: Castro, A., Fernandez, C., Vigneresse, J.L. (Eds.), Understanding Granites: Integrating New and Classical Techniques, vol. 168. Geological Society Special Publication, Geological Society of London, pp. 7-25.

Tsao, S., 1994. Potassium-argon age determination of volcanic rocks from the Tatun Volcanic Group. Bulletin of Central Geological Survey 9, 137-154 (in Chinese with English abstract).

Vidal, Ph., Cocherie, A., Le Fort, P., 1982. Geochemical investigations of the origin of the Manaslu leucogranite (Himalaya, Nepal). Geochimica et Cosmochimica Acta 46, 2279-2292.

Wiedenbeck, M., Alle, P., Corfu, F., Griffin, W.L., Meier, M., Ober, F., von Quandt, A., Roddick, J.C., Spiegel, J., 1995. Three natural zircon standards for $\mathrm{U}-\mathrm{Th}-\mathrm{Pb}, \mathrm{Lu}-\mathrm{Hf}$, trace element and REE analyses. Geostandard Newsletter 19, 1-23.

Wu, K., Yan, B., Wu, Z., Wang, W., 1989. Time sequence and genesis relation of Zhangzhou intrusive complex and Jianweishan volcanic complex. Geology of Fujian 8, 217-240 (in Chinese with English abstract).

Xie, J., Tao, K., Yin, J., Mao, J., Xie, F., Juan, H., Huang, G., Xue, H., Zheng, J., Fong, Z., Yu, Y., 1996. Mesozoic volcanic geology and volcano-intrusive complexes of southeast China continent. People's Republic of China, Ministry of Geology and Mineral Resources, Geological Memoir Number 22, Beijing (in Chinese).

Xing, G., Yang, Z., Tao, K., 1999. Sources of Cretaceous bimodal volcanic rocks in the coastal region of southeastern China. Acta Geologica Sinica 73, 84-92.

Xu, X., O'Reilly, S., Zhou, X., Griffin, W.L., 1996. A xenolith-derived geotherm and the crust-mantle boundary at Qilin, southeastern China. Lithos 38, 41-62.

Yu, Y., Zhou, T., Chen, J., 1993. The characteristics and origin of the Xuentandi bimodal volcanic rocks of the late stage of Early Cretaceous, Zhejiang. Journal of Nanjing University (Earth Science) 5, 420-429 (in Chinese with English abstract).

Yuan, H.L., Gao, S., Liu, X.M., Li, H.M., Günther, D., Wu, F.Y., 2004 Accurate $\mathrm{U}-\mathrm{Pb}$ age and trace element determinations of zircon by Laser Ablation-Inductively Coupled Plasma-Mass Spectrometry. Geostandard Newsletter 28, 353-370.

Zhou, X., Sun, T., Shen, W., Shu, L., Niu, Y., 2006. Petrogenesis of Mesozoic granitoids and volcanic rocks in South China: A response to tectonic evolution. Episodes 29, 26-33.

Zhou, X.M., Li, W.X., 2000. Origin of Late Mesozoic igneous rocks in southeastern China: Implications for lithosphere subduction and underplating of mafic magmas. Tectonophysics 326, 269-287.

Zito, G., 2005. Heat flow anomaly and lithospheric thinning of the Tuscan extensional back-arc basin (Italy). Geodynamics 40, 1-22. 